\title{
Los Tribunales Constitucionales en la región andina: una visión comparativa
}

Francisco Eguiguren Praeli

«Pero desde ahora conviene precisar que un tribunal constitucional es una jurisdicción creada para conocer especial y exclusivamente en materia de lo contencioso constitucional, situada fuera del aparato jurisdiccional ordinario e independiente tanto de éste como de los poderes públicos. Un Tribunal Supremo o, incluso, la cámara constitucional de un tribunal supremo, pueden ser jurisdicciones constitucionales, pero no son Tribunales Constitucionales. En contrapartida, poco importa que éste o aquél Tribunal constitucional se denomine formalmente "Consejo", "Tribunal" o, incluso, "tribunal supremo constitucional", siempre que responda a la definición que acaba de esbozarse» Louis Favoreu ${ }^{1}$.

América ha sido la cuna del control judicial de la constitucionalidad de las leyes pues, como se sabe, a poco de iniciado el siglo XIX se instauró esta práctica en los Estados Unidos de Norteamérica. De allí se extendió, desde mediados de dicho siglo, a diversos países de América Latina como México, Argentina, Brasil, Colombia y Venezuela. Lejos estaba para entonces el mundo europeo de adoptar alguna institución similar, en especial por su culto a la supremacía del parlamento y de la ley (entendida ésta como expresión legítima de la voluntad general) así como por su marcada desconfianza hacia los órganos judiciales. Es por

1 Louis Favoreu: Los Tribunales Constitucionales; Editorial Ariel; Barcelona, España (1994); pp. 13-14. 
ello que la creación de los tribunales constitucionales europeos recién se genera hacia 1920 y en el período de entreguerras, adquiriendo real desarrollo tras la culminación de la Segunda Guerra Mundial.

Sin embargo, durante las últimas décadas también en diversos países de América Latina han empezado a instaurarse Tribunales o Cortes Constitucionales, sin abandonar (del todo) el sistema "difuso" o "americano" de jurisdicción constitucional, buscando recoger o (muchas veces) imitar la exitosa experiencia alcanzada en algunos países europeos, especialmente en Alemania, Italia y España. Este ha sido el camino seguido en los casos de Guatemala (en 1965 y 1985), Chile (1970 y 1980), Ecuador (1978), Perú (1979 y 1993), Colombia (1991) y Bolivia (1994).

En el presente trabajo nos proponemos realizar un somero análisis de las principales características de los distintos tribunales constitucionales existentes en los países de la región andina de Latinoamérica, es decir, en Colombia, Ecuador, Perú, Bolivia y Chile. Nos interesa identificar sus rasgos comunes y sus diferentes particularidades, buscando también determinar cuáles son los principales problemas que los aquejan y ensayar algunas posibles recomendaciones para superarlos.

\section{La adopción de tribunales constitucionales en América Latina}

No puede descartarse que la adopción de los tribunales constitucionales en Latinoamérica se explique, en muchos casos, por la recepción de una suerte de "ola" portadora de experiencias europeas tenidas como exitosas, acogida con entusiasmo en ámbitos académicos y luego promovida hacia los sectores políticos de algunos de nuestros países. Sin embargo, creemos que lo decisivo para su incorporación en los regímenes políticos y constitucionales de la región ha sido la amplia crítica e insatisfacción frente al discreto papel cumplido por su Poder Judicial y la Corte Suprema en la defensa de la supremacía de la Constitución y la protección de los derechos humanos, así como el acentuado escepticismo en que los tribunales ordinarios puedan asumir un rol más activo y resuelto en el control de los excesos del poder político.

Recordemos que este cuestionamiento al papel de los órganos judiciales ordinarios también estuvo presente anteriormente en la experiencia europea, considerándolo Mauro Cappelletti y Louis Favoreu como un 
factor decisivo para la adopción de tribunales constitucionales, autónomos y ajenos al Poder Judicial, en diversos países de Europa continental luego de la segunda gran guerra. Sostiene así Cappelletti que:

«Los jueces de la Europa continental son habitualmente magistrados de "carrera", poco aptos para cumplir una tarea de control de las leyes, tarea que es inevitablemente creadora y va mucho más lejos de la función tradicional de "meros intérpretes" y "fieles servidores" de las leyes. La interpretación misma de las normas constitucionales, y especialmente del núcleo central de éstas, que es la Declaración de los Derechos Fundamentales o "Bill of Rights", suele ser muy distinta de la interpretación de las leyes ordinarias. Requiere una aproximación que se conjuga mal con la tradicional "debilidad y timidez" del juez según el modelo continental» ${ }^{2}$.

Lo anterior, seguramente, explica porqué en países latinoamericanos donde su Corte Suprema posee algún prestigio o aceptación social, la creación de "órganos ad-hoc» como los tribunales constitucionales encuentra mayores resistencias o, incluso, no forma parte de la propuesta de la comunidad académica ni tiene prioridad en la agenda política de la reforma de sus sistemas judiciales. A ello habría que sumar, como un factor corriente y constante, el rechazo o la resistencia de las cortes supremas nacionales al establecimiento de tribunales constitucionales, fundamentalmente desde una posición de "defensa" de su tradicional condición de máximo tribunal jurisdiccional del país, asumiendo que la creación de un nuevo órgano, dotado de la elevada función de ejercer el control de la constitucionalidad, merma su autoridad y restringe sus atribuciones en este campo.

Pero la creación de tribunales constitucionales, encargados de ejercer el control jurisdiccional de la constitucionalidad de las leyes, no sólo se justifica por la necesidad de asignar tal función a un órgano distinto al Poder Judicial. Resulta también una conclusión inevitable, dada la ingenuidad que supondría, a decir de Kelsen, depositar dicha función y encomendar su custodia al propio Parlamento, pues ello

2 Mauro Cappelletti: Cours Constitutionelles; p. 463; citado por Louis Favoreu; op. cit.; p. 19. 
supondría apostar y confiar en su capacidad de autocensura y moderación, algo difícil de esperar por tratarse de un órgano eminentemente político, el mismo que aprueba las leyes. Sostiene así Kelsen que:

«Garantía de la Constitución significa, entonces, garantía de la regularidad de las normas inmediatamente subordinadas a la Constitución, es decir esencialmente garantías de la constitucionalidad de las leyes [...].

No existe hipótesis de garantía de la regularidad en donde se pudiera, estar tentado a confiar la anulación de los actos irregulares al mismo órgano que los ha realizado. Y, ciertamente, en ningún caso este procedimiento estaría más contraindicado; puesto que la única forma en la que se podría ver, en una cierta medida, una garantía eficaz de la constitucionalidad -declaración de la irregularidad por un tercer órgano y obligación del órgano autor del acto irregular de anularlo- es aquel impracticable porque el Parlamento no puede, por su propia naturaleza, ser obligado de manera eficaz. Sería ingenuidad política contar con que el Parlamento anularía una ley votada por él en razón de que otra instancia la hubiera declarado inconstitucional. El órgano legislativo se considera en la realidad como un libre creador del derecho y no como un órgano de aplicación del derecho vinculado a la Constitución, no obstante que lo está, teóricamente, bien que en una medida relativamente reducida.

No es pues el Parlamento mismo con quien se puede contar para realizar su subordinación a la Constitución. Es un órgano diferente a él, independiente de él y, por consiguiente, también de cualquier otra autoridad estatal, al que es necesario encargar la anulación de los actos inconstitucionales, esto es, a una jurisdicción o tribunal constitucionalı ${ }^{3}$.

Quizás por ello resulta fácil de entender la relativa (y también frecuente) desconfianza o cierto desinterés hacia los tribunales constitucionales por parte de quienes conforman los órganos constituyentes o

3 Hans Kelsen: La garantía jurisdiccional de la Constitución; (traducción de Rolando Tamayo y Salmorán); en, Anuario Jurídico; Instituto de Investigaciones Jurídicas, No1 - año 1974; Universidad Nacional Autónoma de México; pp. 474 y 490. 
el Congreso, que son responsables de aprobar las reformas que permitan su creación. Esto puede explicarse por el significativo desconocimiento de muchos políticos acerca del exacto alcance e implicancias de esta nueva institución, pero -en mucho- más bien por el temor a otorgar a los tribunales constitucionales algunas competencias que conllevan -en lo esencial- precisamente el control del accionar legislativo del propio Congreso y de los actos gubernamentales.

Estas circunstancias fácticas y políticas, antes que elaboraciones abstractas o conceptuales predeterminadas, consideramos que explican el peculiar carácter "híbrido" del "modelo" adoptado en el sistema de jurisdicción constitucional instaurado en los países latinoamericanos que han establecido tribunales constitucionales, donde los "clásicos" sistemas "difuso" y "concentrado" conviven simultáneamente -a pesar que desde una visión teórica o "pura» pudiera calificárseles como «incompatibles». El resultado suele ser un sistema "mixto" o «dual», según cada caso, con un Poder Judicial o una Corte Suprema, de un lado, y un Tribunal o Corte Constitucional, del otro, que ejercen simultáneamente determinadas competencias y separadas atribuciones jurisdiccionales en materia constitucional.

De todos modos, por encima de cualquier objeción a la "pureza" teórica del sistema resultante o a las deficiencias en el funcionamiento práctico de la jurisdicción constitucional surgida en los países latinoamericanos que han adoptado tribunales constitucionales, tenemos la convicción de que la instauración de dichos tribunales ha sido -en la gran mayoría de casos- expresión de una sincera y genuina esperanza de que su accionar contribuya a fortalecer la vigencia del Estado de Derecho, la supremacía de la Constitución y la protección de los derechos fundamentales. Por ello se impone analizarlos desde una perspectiva constructiva y optimista, que cree en su importancia y aporta a su desarrollo y consolidación.

2. La opción por un sistema de tipo "mixto" o "dual» de jurisdicción constitucional

Se suele aludir en el derecho constitucional comparado a la existencia de tres «modelos» originarios o clásicos de jurisdicción constitucio- 
nal $^{4}$ o de justicia constitucional, con relación al control de la constitucionalidad de las leyes. Se trata de los denominados sistemas "americano" o "difuso", «europeo" o "concentrado», y "político». Nos interesa detenernos en los dos primeros, por su naturaleza más estrictamente jurisdiccional.

Sostiene Domingo García Belaunde que fue Calamandrei, en una monografía de los años cincuenta, quien formuló una clasificación del control jurisdiccional de la constitucionalidad que se ha hecho clásica y que luego ha sido desarrollada por Fix Zamudio y Cappelletti, contemplando dos modelos: uno "judicial" y otro "autónomo». Al primero corresponde un carácter difuso, incidental, especial y declarativo; mientras que el segundo se define por su naturaleza concentrada, principal, especial y constitutiva ${ }^{5}$. Tales características corresponden, respectivamente, a los denominados sistemas o modelos «difuso» $\mathrm{o}$ «americano" y "concentrado" o "europeo". Veamos:

El sistema "difuso" o modelo "americano", es aquel donde el control de la Constitución es ejercido por todos los jueces y tribunales judiciales del país; se le conoce también como "sistema de revisión judicial" ("judicial review") y surgió en los Estados Unidos de América del Norte a partir del precedente establecido por el juez Marshall y la

4 Entendemos por jurisdicción constitucional (o justicia constitucional) al conjunto de procesos y mecanismos procesales o judiciales establecidos para asegurar y garantizar la supremacía y vigencia de la Constitución, a través de la intervención de un órgano jurisdiccional, tanto con respecto al control de la constitucionalidad de las leyes y normas jurídicas como de la protección y defensa de los derechos constitucionales. Obviamente esta definición resulta mucha más extensa que la considerada en la clásica clasificación de los sistemas de jurisdicción constitucional como "difuso", "concentrado" o "político"; construida esencialmente frente a la modalidad de ejercer el control de la constitucionalidad de las leyes. Por lo demás, siguiendo a García Belaunde, parece previsible que cada vez más la noción de jurisdicción constitucional -como producto de su evolución y enriquecimiento conceptual-vaya siendo reemplazada por la nueva disciplina del Derecho Procesal Constitucional, dentro de la cual quedará contenida.

5 Cf. Domingo García Belaunde: «La jurisdicción constitucional y el modelo dual o paralelo"; en, La Ley, año LXII, N 197; Buenos Aires, viernes 16 de octubre de 1998; p. 1. Este interesante trabajo se encuentra también publicado en "La justicia constitucional a finales del siglo $\mathrm{XX}_{\Perp}$; Revista del Instituto de Ciencias Políticas y Derecho Constitucional, año VII, N 6; Palestra editores: Huancayo, Perú (1998); pp. 139-154. 
Suprema Corte en el caso Marbury vs. Madison en 1803. Tiene como fundamento la supremacía de la Constitución, cuya vigencia efectiva impone a todo juez, en cualquier tipo de proceso judicial, el deber de preferir la norma constitucional y dejar de aplicar (en el caso específico) cualquier ley o disposición que la vulnere o contradiga; estas normas son consideradas nulas por inconstitucionales $y$, como tales, deben ser dejadas de lado para la solución del caso particular objeto de juzgamiento. No obstante, la ley continuará formalmente vigente, pues la decisión judicial se restringe a un caso preciso y a las partes involucradas en él, sin tener alcance general o efecto erga omnes.

El sistema "difuso" conlleva una suerte de control «incidental», pues se efectúa en el marco de un proceso judicial que no tiene como objeto principal analizar la constitucionalidad de una norma. Sin embargo, el control de la constitucionalidad de la norma se genera ante la necesidad de dilucidar si una ley necesaria de aplicar para resolver el caso, resulta constitucional o no; en caso negativo, se declara su inconstitucionalidad, se inaplica la norma en dicho caso pero el juez o tribunal no la anulan, ni ésta pierde vigencia general.

El sistema "concentrado" o "europeo" (también conocido como modelo austríaco) en cambio, está inspirado en la creación teórica de Hans Kelsen; supone que el control de la constitucionalidad de las leyes y actos gubernamentales reside exclusivamente en un órgano adhoc y autónomo, el Tribunal (o Corte) Constitucional, especialmente creado para estos efectos. Es un control "principal" y abstracto de la constitucionalidad de una ley o norma, pues el caso se motiva en una acción judicial directa y exclusivamente encaminada a este propósito (en vez de suscitarse en el marco de un proceso judicial cualquiera, dirigido a otro propósito central) por lo que la resolución que establece la inconstitucionalidad tiene carácter constitutivo, acarrea la anulación (para el futuro) y la derogación de la norma, siendo los efectos de su sentencia generales o erga omnes.

Conforme señala Brewer-Carías, el sistema «difuso" norteamericano ejerció notoria influencia en Latinoamérica desde mediados del siglo XIX y hasta más de la mitad del XX. Así anota que fue adoptado, de una u otra forma, en Argentina (1860), México (1857), Venezuela (1858), Brasil (1890), República Dominicana (1844), Colombia (1850). Sin embargo, precisa que la tendencia predominante en América latina ha sido la evolución hacia el establecimiento de un "sistema mixto", 
agregando posteriormente al control difuso el sistema concentrado radicado, en unos casos, en la Corte Suprema o, en otros, en Tribunales Constitucionales; funcionando ambos simultáneamente, o adoptando -en el caso de algunos países- desde el principio dicho modelo mixto ${ }^{6}$.

García Belaunde, por su parte, introduce una muy interesante distinción al interior de estos modelos "derivados», diferenciando el modelo «mixto» de otro que denomina «dual» o «paralelo». Afirma que si bien ambos surgen por la incorporación del modelo concentrado o europeo en países que ya tenían adoptado (y mantienen) el sistema americano o difuso, el sistema mixto se genera cuando se produce una mezcla de elementos constitutivos de los dos modelos clásicos, que dan lugar a un "tercero" que no es lo que son los dos anteriores pero tampoco algo enteramente autóctono y original. «En cambio, el modelo dual o paralelo es aquel que existe cuando en un mismo país, en un mismo ordenamiento jurídico, coexisten el modelo americano y el modelo europeo, pero sin mezclarse, deformarse ni desnaturalizarse. $\mathrm{Y}$ esto, que no es frecuente, tiene su partida de nacimiento en la Constitución peruana de 1979, reiterada en la vigente Carta de 1993 [...]. Lo mixto supone una mixtura, una mezcla de dos o más elementos, que en el caso peruano no sólo no se mezclan sino que tampoco originan un tertium que sea distinto a sus dos fuentes de origen ${ }^{7}$.

A la luz de las observaciones y criterios esbozados por Brewer Carías y García Belaunde, conviene echar una mirada a la naturaleza de los sistemas de control jurisdiccional de la constitucionalidad de las leyes actualmente existentes en los países latinoamericanos que han incorporado tribunales constitucionales, manteniendo la experiencia anterior del control difuso a cargo del órgano judicial ordinario. Tenemos así que:

6 Cf. Allan Brewer-Carías: «La Justicia Constitucional en América Latina»; en, Derecho Público, Filosofía y Sociología Jurídicas: perspectivas para el próximo milenio (Memorias del Congreso Internacional); Universidad Externado de Colombia y Consejo Superior de la Judicatura; (Bogotá, Dic. 1996); p. 470. Este trabajo está también publicado en el colectivo La Justicia Constitucional en Iberoamérica; Domingo García Belaunde y Francisco Fernández Segado (coordinadores); Dykinson (España), Ediciones Jurídicas (Perú), Editorial Jurídica Venezolana y Edit. Jurídica E. Esteva (Uruguay); Madrid (1997); p. 123.

7 Domingo García Belaunde: La jurisdicción constitucional y el modelo dual o paralelo; op. cit. ; p. 2. 
- En Ecuador, tras la reforma constitucional de 1998 a la Carta de 1978, se establece en el Art. $274^{\circ}$ un control concreto e incidental por cualquier juez y en cualquier proceso judicial, donde (de oficio o a petición de parte) se puede declarar la inconstitucionalidad de una norma contraria a la Constitución, sin perjuicio de fallar sobre el asunto principal controvertido; la declaración de inconstitucionalidad se limita al caso específico. La decisión de la Corte Suprema o el tribunal de última instancia que declara la inaplicación de la norma inconstitucional, origina un informe ante el Tribunal Constitucional para que éste resuelva sobre la inconstitucionalidad con carácter general y obligatorio. Por su parte, según el Art. $276^{\circ}$, el Tribunal Constitucional es competente para conocer de las acciones de inconstitucionalidad dirigidas contra leyes, decretos-leyes, decretos, reglamentos y ordenanzas y actos administrativos de cualquier autoridad pública. Se trata, en opinión de García Belaunde, de un sistema dual o paralelo, aunque estimamos que las recientes reformas introducidas tienden a establecer ciertas relaciones entre la Corte Suprema y el Tribunal Constitucional en este campo.

- En Chile, el Art. 80 de la Constitución de 1980 faculta a la Corte Suprema a ejercer el control incidental de la constitucionalidad de las leyes, declarando -cuando corresponda- su inaplicación al caso concreto. A su vez, el Art. $82^{\circ}$ de la Carta Política confiere al Tribunal Constitucional atribuciones para ejercer el control previo de la constitucionalidad de las leyes orgánicas y de las leyes interpretativas de la Constitución antes de su promulgación, de los proyectos de ley durante su tramitación, de los tratados sometidos para aprobación del Congreso y de los decretos con fuerza de ley. En consecuencia, el control de inaplicación, para el caso específico, está "concentrado" en la Corte Suprema, mientras que el Tribunal Constitucional efectúa un control preventivo más cercano al papel de filtro político del accionar legislativo. Ello lleva a García Belaunde a catalogarlo como un sistema que, a pesar de contar con semejanzas al modelo dual o paralelo (dado que la Corte y el Tribunal no entrecruzan sus respectivas competencias) corresponde mejor a una suerte de sistema (político) sui generis, de influencia francesa, pues sostiene que el Tribunal Constitucional tendría una función más política que jurisdiccional ${ }^{8}$. 
- En Colombia, el Art. $241^{\circ}$ de la Constitución de 1991 reserva para la Corte Constitucional la resolución de las acciones de inconstitucionalidad promovidas por los ciudadanos contra las leyes y decretos con fuerza de ley dictados por el Gobierno; asimismo determinar la constitucionalidad de los decretos legislativos, de las leyes estatutarias (orgánicas) y de los proyectos de ley objetados por el Gobierno. A su vez, el Art. $4^{\circ}$ de la propia Constitución dispone: «La Constitución es norma de normas. En todo caso de incompatibilidad entre la Constitución y la ley u otra norma jurídica, se aplicarán las disposiciones constitucionales»; esta norma consagra el control difuso por cualquier juez o tribunal. Y en el Art. $237^{\circ}$ inciso 2, se encarga al Consejo de Estado conocer de la nulidad de los decretos gubernamentales sin fuerza de ley acusados de inconstitucionalidad. Se inscribiría dentro del sistema mixto, aunque la labor de la Corte Constitucional viene plasmando un sistema "real" que tiende a orientarse hacia formas de control concentrado de la constitucionalidad de las normas legales.

- En el Perú, la Constitución de 1993 (siguiendo el esquema planteado en la Carta de 1979) establece el control difuso en el segundo párrafo de su Art. $138^{\circ}$ cuando dispone: «En todo proceso, de existir incompatibilidad entre una norma constitucional y una norma legal, los jueces prefieren la primera. Igualmente prefieren la norma legal sobre toda otra norma de rango inferior". Y en el Art. 202 inciso 1, hace competente al Tribunal Constitucional para conocer y resolver, en instancia única, las acciones de inconstitucionalidad promovidas contra leyes, decretos legislativos, decretos de urgencia, tratados, reglamentos del Congreso, normas regionales de carácter general y ordenanzas municipales. Aquí se configuraría un sistema dual o paralelo, pues los modelos difuso y concentrado coexisten de forma simultánea pero separada.

- En Bolivia, la Constitución de 1967, en el artículo $228^{\circ}$, garantiza la supremacía de la Constitución e impone a los jueces, tribunales y autoridades aplicarla con preferencia a las leyes. A su vez, tras la sustancial reforma constitucional de 1994, en el inciso 1 del Art. $120^{\circ}$ de la Carta se encarga al Tribunal Constitucional realizar el control abstracto -en única instancia- de la constitucionalidad de las leyes, decretos y resoluciones judiciales; así como también es competente para resolver, con carácter obligatorio, el recurso indi- 
recto o incidental de inconstitucionalidad que se promueva en cualquier proceso judicial, para determinar si la norma a aplicar para decidir el caso es o no compatible con la Constitución. Estaríamos ante un sistema formalmente mixto, pero con indudable tendencia hacia un modelo concentrado, que es -al parecer- lo que se quiso instaurar con la reforma constitucional.

Sin perjuicio de la utilidad conceptual y didáctica de esta caracterización, creemos oportuno precisar (recordando lo dicho al inicio de este punto) que la clasificación de los sistemas de jurisdicción constitucional en los modelos "difuso o americano" y "concentrado o europeo», así como en sus variables derivadas «mixta" $\mathrm{y}$ "dual o paralela», ha sido construida esencialmente con base al control de la constitucionalidad de las leyes y normas. Ello hace que actualmente tal clasificación resulte insuficiente, en primer lugar, por las múltiples variaciones producidas en los países generadores de los modelos originarios y en otros que los han adoptado, así como por las peculiaridades de las incontables fórmulas derivadas (mixtas o duales) surgidas; pero, sobre todo, por el hecho trascendental de que la jurisdicción constitucional y los tribunales ya no sólo se ocupan del control de la constitucionalidad de las leyes o normas, sino que también -y muchas veces con mayor frecuencia y relevancia- ejercen la protección y la custodia de la vigencia de los derechos constitucionales.

Desde hace ya varios años, Favoreu advertía como una tendencia en los principales tribunales constitucionales europeos el desplazamiento de su actuación preferente del control de la constitucionalidad de las leyes al control de su aplicación. Así, sostiene, los tribunales constitucionales alemán, español e italiano se convierten -cada vez más- en una suerte de «supertribunales de casación» o de última instancia para la protección de los derechos fundamentales, ya sea a través de los recursos de amparo por la violación de derechos constitucionales, por la alegación de vulneraciones al debido proceso en resoluciones judiciales, o por el análisis de "cuestiones de inconstitucionalidad" promovidas en el marco de procesos judiciales ordinarios ${ }^{9}$. En similar dirección apuntaba Jean Rivero cuando, en su ponencia de conclusión del coloquio realizado en Aix (en Provence) en 1981, señalaba como la gran revolu-

9 Cf. Louis Favoreu: op. cit.; p. 41. 
ción del Derecho público europeo contemporáneo la irrupción y consolidación del tema de los derechos fundamentales y su protección como aspecto crucial en el quehacer de los tribunales constitucionales ${ }^{10}$.

Por ello encontramos muy sugerente y atractiva la propuesta que formula Rubio Llorente, quien prefiere distinguir actualmente dos grandes modelos en la jurisdicción constitucional -en atención al eje central de su finalidad o interés- un modelo que se propone asegurar la constitucionalidad de la ley (en especial para preservar el control de la división de poderes) y otro que procura garantizar la vigencia de los derechos constitucionales. Aunque obviamente este autor reconoce la vinculación e interdependencia entre ambos aspectos, como componentes de la jurisdicción constitucional, afirma la tendencia prevaleciente en la actualidad hacia el modelo centrado en la vigencia de los derechos. Así, buscando explicar y fundamentar la causa de este fenómeno, sostiene que "el hecho que el control de la constitucionalidad de la ley es, en sí mismo, simplemente instrumental; el aseguramiento de la constitucionalidad de las leyes no persigue otra finalidad que garantizar la vigencia de los derechos y que, en consecuencia, la razón de ser de la tendencia es inherente a la idea misma de jurisdicción constitucional» ${ }^{11}$.

\section{Principales características y atribuciones de los Tribunales Cons- titucionales de la región andina.}

\subsection{Origen, naturaleza, ubicación y marco regulatorio}

Los tribunales y cortes constitucionales de Chile, Ecuador y Perú están concebidos en sus respectivos ordenamientos constitucionales como órganos autónomos, distintos y separados del Poder Judicial. En cam-

10 Cf. Jean Rivero: "A modo de síntesis"; en, Tribunales constitucionales europeos y derechos fundamentales; Centro de Estudios Constitucionales; Madrid, Espaก๊a (1984); p. 664.

11 Francisco Rubio Llorente: "Tendencias actuales de la jurisdicción constitucional en Europa»; en, La jurisdicción constitucional chilena ante la reforma; AA. VV. (Gastón Gómez B.; editor); Escuela de Derecho de la Universidad Diego Portales; Cuadernos de Análisis Jurídico 41; Santiago de Chile (1999); p. 53. 
bio, la Corte Constitucional de Colombia forma parte de la denominada "rama judicial", integrada también por la Corte Suprema, el Consejo de Estado, el Consejo Superior de la Judicatura, la Fiscalía General de la Nación, los tribunales y jueces ordinarios y la Justicia penal militar. A su vez, el Tribunal Constitucional de Bolivia está definido por la Constitución como un órgano que integra el Poder Judicial, conjuntamente con la Corte Suprema, el Consejo de la Judicatura, las Cortes superiores de distrito, los tribunales y jueces.

Si bien la existencia autónoma y separada del tribunal constitucional, con respecto al Poder Judicial, resulta una exigencia totalmente justificada tanto desde una perspectiva conceptual como de su funcionamiento práctico, la inclusión formal de la Corte Constitucional colombiana dentro de la rama judicial y del Tribunal Constitucional de Bolivia como parte del Poder Judicial, viene demostrando hasta el momento, a partir de su actuación jurisdiccional y administrativa, no ser un obstáculo para su autonomía e independencia orgánica y funcional.

En Chile, la Constitución de 1833 no contemplaba forma alguna de control constitucional de las normas; es más, conforme anota Gómez Bernales, la Corte Suprema rechazó expresamente que los tribunales pudieran decidir sobre la constitucionalidad o inaplicación de las leyes, sosteniendo que el deber del juez era aplicarlas y no juzgarlas ${ }^{12}$. Fue la Constitución de 1925 la que introdujo, en el inciso 2 del Art. $86^{\circ}$, el control judicial por la Corte Suprema de la constitucionalidad de las leyes, mediante el denominado «recurso de inaplicación», a ser promovido en cualquier proceso e instancia, para que se declare inaplicable en el caso concreto la norma descalificada por inconstitucional.

El Tribunal Constitucional chileno fue instituido mediante la reforma constitucional aprobada por la Ley $\mathrm{N}^{\circ} 17.284$ del 23 de enero de 1970, que adicionó los incisos a), b) y c) del Art. $78^{\circ}$. Dicho Tribunal Constitucional estaba integrado por cinco miembros, tres de ellos designados por el Presidente de la República en acuerdo con el Senado y los dos restantes por la Corte Suprema de entre sus miembros. Dentro de sus atribuciones más importantes destacaba la resolución de las cuestiones sobre constitucionalidad que se susciten durante la tramitación de los proyectos de ley y de los tratados sometidos a aprobación

12 Cf. Gastón Gómez Bernales: «La Justicia Constitucional en Chile»; en, Anuario Iberoamericano de Justicia Constitucional 1997; op. cit.; p. 122. 
del Congreso; así como el control de la constitucionalidad de los decretos con fuerza de ley. Este Tribunal fue disuelto tras el golpe de estado de 1973.

La Constitución chilena de 1980 restableció el Tribunal Constitucional, ocupándose de él en sus artículos $81^{\circ}$ al $83^{\circ}$, algunas de cuyas normas fueron modificadas dentro de la Ley de reforma constitucional $\mathrm{N}^{\circ} 18.825$ del 17 de agosto de 1989. Su organización, atribuciones y funcionamiento han sido desarrolladas en la Ley orgánica del Tribunal Constitucional $\mathrm{N}^{\circ}$ 17.997, del 12 de mayo de 1981. El sistema chileno de jurisdicción constitucional combina así un control preventivo de constitucionalidad, a cargo del TC, con respecto a las leyes orgánicas e interpretativas de la Constitución, antes de su promulgación, así como de proyectos de ley en trámite parlamentario; con un control $a$ posteriori de la constitucionalidad de las leyes vigentes, ejercido exclusivamente por la Corte Suprema a través del recurso de inaplicación, cuyas resoluciones tienen efecto sólo para el caso concreto y las partes involucradas.

En el Ecuador, sostiene Salgado Pesantes, el intento de adoptar un sistema de jurisdicción constitucional se inicia con la Constitución de 1945 y el establecimiento de un Tribunal de Garantías Constitucionales que, aunque tomaba como referente al de la República española de 1931, asumía algunas competencias propias de un tribunal de sus características y otras ajenas, en parte por sustituir en sus funciones al Consejo de Estado ${ }^{13}$. Dicho TGC, en materia de control de constitucionalidad, debía formular observaciones sobre las normas jurídicas (distintas a las leyes) que fueran inconstitucionales o ilegales; en cambio, tratándose de las leyes, el TGC sólo podía suspenderlas y remitirlas al Congreso para que éste adopte la decisión definitiva sobre su constitucionalidad y vigencia. Agrega este autor que al tribunal correspondía también el control de los proyectos de ley o decreto, que luego fue dejado de lado. La vigencia de dicha Constitución y del TGC fueron realmente efímeras, al quedar sin efecto por la Constitución de 1946.

13 Cf. Hernán Salgado Pesantes: "La Justicia Constitucional en Ecuador»; en, Anuario Iberoamericano de Justicia Constitucional 1997; op. cit.; pp. 157-159. Igualmente su trabajo, "La Jurisdicción Constitucional en el Ecuador»; en: La Jurisdicción Constitucional en Iberoamérica; op. cit, pp. 577-578. 
La Constitución del Ecuador de 1978 restableció la existencia del Tribunal Constitucional y lo igula en sus artículos $275^{\circ}$ al $279^{\circ}$; el desarrollo de su organización, atribuciones y funcionamiento se encuentra normado en la «Ley del Control Constitucional», aprobada por el Congreso el 18 de junio de 1997. En el artículo $3^{\circ}$ de dicha ley se define al Tribunal Constitucional "como órgano supremo de control constitucional», afirmando su carácter independiente frente a las otras funciones y órganos del Estado, así como su autonomía administrativa y presupuestaria.

En el sistema ecuatoriano actual conviven el control incidental de inaplicación, a cargo de cualquier juez y de las salas de la Corte Suprema y Tribunales de última instancia, con el control general a cargo del Tribunal Constitucional, aunque -según sostiene Salgado Pesantes- se pretendía avanzar hacia un sistema concentrado a pesar de las incongruencias y resistencias políticas. Cabe considerar como un retroceso la reforma introducida en 1992, que dispuso que las resoluciones del TC que consideraban inconstitucional una ley sólo suspendían su vigencia y debían ser remitidas a la nueva Sala Constitucional de la Corte Suprema, para que ésta (cumpliendo el papel que antes desempeñaba el Congreso) emita una decisión definitiva y de alcance general en la materia. Luego, una positiva reforma aprobada en 1996 (confirmada con la Ley de Control Constitucional de 1997 y la reforma constitucional de 1998) ha dispuesto que las resoluciones del Tribunal Constitucional acerca de leyes, decretos-leyes, decretos, ordenanzas y actos administrativos hallados inconstitucionales adquieren carácter definitivo, inapelable, con efectos generales pero no retroactivos. Con la reforma también se ha conferido al TC el control previo de los proyectos de ley, cuya constitucionalidad haya sido objetada por el Presidente de la República durante su trámite de formación.

Por su parte, el Tribunal de Garantías Constitucionales del Perú fue instituido por la Constitución de 1979. Aunque sus atribuciones proyectadas durante el debate constituyente fueron inicialmente bastante amplias y ambiciosas, finalmente la Carta aprobada sólo lo hizo competente para conocer (en instancia única y con efectos generales) del control directo y principal de la constitucionalidad de las leyes mediante la acción de inconstitucionalidad; así como de la casación (con efectos de reenvío y no de última instancia) de las resoluciones judiciales denegatorias de las acciones de hábeas corpus y amparo. El Poder Judicial 
conservaba el control difuso de la constitucionalidad de las leyes. El TGC ejerció sus funciones entre 1983 y 1992, siendo clausurado y suprimido por el autogolpe de estado del presidente Fujimori del 5 de abril de dicho año. Su actuación, en general, resultó discreta, sufriendo incluso un progresivo decaimiento ${ }^{14}$.

Este mismo modelo "dual o paralelo", se ha mantenido en la actual Constitución de 1993, que volvió a instituir un Tribunal Constitucional, a pesar que en las propuestas iniciales de la mayoría oficialista en el congreso constituyente tal posibilidad aparecía expresamente descartada. De conformidad con el artículo $201^{\circ}$ de la Carta, el Tribunal Constitucional es el «órgano de control de la Constitución»; es autónomo e independiente de los demás órganos constitucionales. El Poder Judicial sigue ejerciendo el control difuso de la constitucionalidad de las normas y el TC conoce de las acciones de inconstitucionalidad

14 Para analizar el desarrollo y funcionamiento de la jurisdicción constitucional en el Perú, pueden revisarse el colectivo Sobre la Jurisdicción Constitucional (Aníbal Quiroga León, compilador), Pontificia Universidad Católica del Perú - Fondo Editorial (Lima, 1990); donde se publican trabajos de Domingo García Belaunde, Francisco Eguiguren Praeli, Marcial Rubio Correa, Samuel Abad Yupanqui y Aníbal Quiroga León, sobre diversos temas de esta materia. Asimismo, Francisco Eguiguren Praeli: «El Tribunal de Garantías Constitucionales: las limitaciones del modelo y las decepciones de la realidad"; en, Lecturas sobre temas constitucionales 7; Comisión Andina de Juristas (Lima, oct. 1991); pp. 15-59. César Landa Arroyo: "Del tribunal de garantías al tribunal constitucional $n$; en Pensamiento Constitucional $\mathrm{N}^{\circ} 2$; revista de la Maestría en Derecho Constitucional de la Universidad Católica (1995); pp. 73114. Ernesto Blume Fortini: «El tribunal constitucional peruano como supremo intérprete de la Constitución»; en: Pensamiento Constitucional No 3 (1996); pp. 293-337. Samuel Abad Yupanqui: «La jurisdicción constitucional en el Perú: antecedentes, balance y perspectivas"; en, Anuario de Derecho Constitucional Latinoamericano 1996; CIEDLA - Fundación Konrad Adenauer (Buenos Aires, 1996) pp. 107-161. Domingo García Belaunde: «La Jurisdicción Constitucional en Perú»; en: La Jurisdicción Constitucional en Iberoamérica; op. cit, pp. 827-854. Samuel Abad Yupanqui: "La justicia constitucional en Perú»; en: Anuario Iberoamericano de Justicia Constitucional 1997; op. cit, pp. 303-324. Francisco Eguiguren Praeli: «Relaciones entre el Poder Judicial y el Tribunal Constitucional en el Perú: la evolución del modelo y los nuevos problemas»; en: Pensamiento Constitucional No 5 (1998) pp. 115-133. Enrique Bernales Ballesteros: El Tribunal Constitucional Peruano; CIEDLA, Fundación K. Adenauer (1999). César Landa Arroyo: Tribunal Constitucional y Estado Democrático; Pontificia Universidad Católica del Perú - Fondo Editorial; Lima (1999). 
contra leyes y normas de rango legal, con efectos generales y derogatorios, precisándose (en la ley orgánica del Tribunal Constitucional $\mathrm{N}^{\circ}$ 26435, del 10 de enero de 1995) que el órgano judicial no podrá inaplicar las leyes cuya inconstitucionalidad haya sido desestimada por el Tribunal Constitucional. Las acciones de hábeas corpus y amparo, así como las nuevas de hábeas data y de cumplimiento, son de competencia compartida de ambos órganos, y si bien el TC sólo conoce las acciones denegadas ante el Poder Judicial, esta vez su sentencia es la última instancia y pone fin al proceso. La acción popular contra los decretos de carácter general y reglamentos contrarios a la Constitución o la ley, sigue siendo de competencia exclusiva del Poder judicial.

En Colombia, la Corte Constitucional fue introducida por la Constitución de 1991, que lo regula en los arts. $239^{\circ}$ a $245^{\circ}$. Con anterioridad, como explica Eduardo Cifuentes, fue la reforma constitucional de 1910 la que introdujo propiamente un sistema de jurisdicción constitucional en Colombia, encargando a la Corte Suprema conocer de las objeciones del Presidente de la República a la constitucionalidad de los proyectos de ley, así como de las acciones de inconstitucionalidad contra las leyes y decretos con fuerza de ley promovidas por cualquier ciudadano; al lado de este control concentrado, a cargo de la Corte Suprema, se estableció el control difuso, que mandaba preferir -en todo proceso- la norma constitucional frente a cualquier ley o norma inferior que la contravenga ${ }^{15}$.

La reforma constitucional de 1945, hizo competente al Consejo de Estado (máxima autoridad judicial en lo contencioso-administrativo) para las acciones de nulidad en contra de decretos gubernamentales sin fuerza de ley. La reforma constitucional de 1968 estableció una Sala Constitucional en la Corte Suprema, que debía preparar los proyectos de resolución en asuntos de control de constitucionalidad para la decisión que debía adoptar la Corte en pleno. También incorporó el control automático por la Corte Suprema de los decretos dictados por el Gobierno durante los estados de excepción.

Con la creación de la Corte Constitucional, ésta asumió competencias de control de la constitucionalidad de las leyes y normas con fuerza de ley que anteriormente concentraba la Corte Suprema; a ello se su-

15 Cf. Eduardo Cifuentes Muñoz: «La Jurisdicción Constitucional en Colombia»; en, La Jurisdicción Constitucional en Iberoamérica; pp. 473-474. 
man algunas nuevas atribuciones, dentro de las que cabe destacar el control preventivo de constitucionalidad de los proyectos de leyes estatutarias (orgánicas) y la revisión de las sentencias en acciones de tutela dispuestas por el órgano judicial en materia de protección de derechos constitucionales. El sistema de jurisdicción constitucional previsto en la Carta Política de 1991, está desarrollado en la Ley Estatutaria de la Administración de Justicia (de 1996) cuyo capítulo IV se ocupa del tema, en los arts. $43^{\circ}$ al $49^{\circ}$. Cabe agregar el Decreto presidencial $N^{\circ} 2067$ de 1991 (4-9-1991) que reguló la tramitación de los procesos judiciales ante la Corte Constitucional; así como el Acuerdo 5 de 1992 de la propia Corte que aprueba su Reglamento y el Acuerdo 1 de 1994 (del 17-2-94) que le introduce algunas modificaciones.

En Bolivia, el Tribunal Constitucional fue establecido en el marco de la reforma constitucional de 1994, siendo el más reciente en Latinoamérica, pues inició la atención de causas en junio de 1999. Según la Constitución de 1967, en su Art. $127^{\circ}$ inc. 5, la Corte Suprema era competente para "conocer en única instancia de los asuntos de puro derecho cuya decisión dependa de la constitucionalidad o inconstitucionalidad de las leyes, decretos y cualquier género de resoluciones». Con la reforma de 1994, quedó establecido que «el control de constitucionalidad se ejerce por el Tribunal Constitucional" (Art. $116^{\circ}$, inc. IV); la Ley $\mathrm{N}^{\circ} 1836$ (del $1^{\circ}$ de abril de 1998 ) regula y desarrolla todo lo referente a las competencias, procedimientos, organización y funcionamiento del Tribunal Constitucional.

El Tribunal Constitucional de Bolivia cuenta con amplias y variadas competencias, en materia del control de la constitucionalidad de las normas (tanto en vía directa como incidental), la protección de los derechos fundamentales, la absolución de consultas y el control de la regularidad constitucional de diversos actos y decisiones de distintas autoridades estatales. Si bien la reforma de 1994 pareciera que buscaba adoptar un sistema concentrado de control de constitucionalidad a través del Tribunal Constitucional, subsiste en la Carta Política el artículo $228^{\circ}$ (que no fue objeto de reforma) y que tras afirmar la supremacía de la Constitución, manda a todos los tribunales, jueces y autoridades aplicarla con preferencia sobre las leyes, lo que conduce obviamente a la posibilidad del control judicial difuso. 


\subsection{Composición de los Tribunales Constitucionales, designación y estatuto de sus magistrados}

El Tribunal Constitucional de Chile es un órgano especial, autónomo e independiente. Como recuerda el profesor Humberto Nogueira ${ }^{16}$, el primer TC creado en 1970 estaba integrado por cinco miembros: dos de ellos eran designados por la Corte Suprema de entre sus ministros, en una sola votación en la que cada magistrado tenía un solo voto, lo que determinaba que los elegidos correspondían a las dos primeras mayorías relativas de la Corte; los tres miembros restantes eran designados por el Presidente de la República con acuerdo del Senado, debiendo uno de ellos haber desempeñado cátedra universitaria en Derecho público como profesor titular.

Por su parte, el Tribunal Constitucional establecido en el artículo $80^{\circ}$ de la Constitución de 1980 , se compone de siete miembros, que reciben la denominación de ministros; su mandato es de ocho años, renovándose parcialmente cada cuatro años, siendo admisible la reelección. El Tribunal designa cinco abogados integrantes que, en orden de precedencia, son llamados en casos de ausencia del ministro titular. Al igual que los magistrados del Poder Judicial, los ministros del Tribunal sólo pueden ser aprehendidos por mandato del tribunal competente, salvo en caso de flagrante delito, supuesto en el que serán puestos inmediatamente a disposición del órgano judicial.

De los siete ministros del Tribunal Constitucional, tres son elegidos por la Corte Suprema de entre sus miembros, en votaciones secretas y sucesivas para cada uno, lo que justifica la crítica expuesta por Gastón Gómez en el sentido que una misma mayoría de la Corte puede imponer la designación de los tres ministros ${ }^{17}$. Los restantes cuatro miembros son abogados, dos de ellos designados por el Consejo de Seguridad Nacional, uno por el Presidente de la República y el otro por el Senado, con el voto favorable de la mayoría absoluta de sus integrantes. Dichos abogados deben contar con quince años de titulados, haber ejercido funciones en la actividad profesional, universitaria o pública y no padecer los impedimentos fijados para ser juez. En el caso de los

16 Cf. Humberto Nogueira Alcalá: «La Jurisdicción Constitucional en Chile»; en, La Jurisdicción Constitucional en Iberoamérica; op. cit.; p. 544.

17 Cf. Gastón Gómez Bernales: op. cit; p. 129. 
designados por el Presidente de la República y por el Senado, se les exige como requisito adicional haberse desempeñado como abogados integrantes de la Corte Suprema, cuando menos por tres años consecutivos.

Coincidimos plenamente con Nogueira Alcalá en la crítica a la actual composición y forma de designación de los miembros del Tribunal Constitucional chileno. De un lado, por la inconveniencia de que los ministros designados por la Corte Suprema pertenezcan simultáneamente a ésta y al TC, tanto por el menoscabo que conlleva a la efectiva autonomía y separación entre ambos órganos, como porque la experiencia comparada aconseja que los magistrados del Tribunal no provengan de la carrera judicial. De otro lado, por la injustificada potestad del Consejo de Seguridad Nacional de intervenir en la conformación del TC; finalmente, porque tampoco aparece razonable que dos de los abogados designados tengan que haber sido previamente integrantes de la Corte Suprema cuando menos por tres años consecutivos ${ }^{18}$.

En el Ecuador, la Constitución de 1978 previó originalmente que el Tribunal Constitucional estuviera compuesto por once miembros; posteriormente, las reformas de 1983 y 1996 redujeron su número a nueve vocales, con sus respectivos suplentes, siendo designados por el Congreso de la manera siguiente: dos, elegidos de ternas enviadas por el Presidente de la República; dos, elegidos de ternas enviadas por la Corte Suprema, de personas ajenas a su seno; dos elegidos por el Congreso, que no pueden ser legisladores; uno, de la terna enviada por los alcaldes municipales y prefectos provinciales; uno, de la terna enviada por las centrales de trabajadores y organizaciones campesinas e indígenas; y, uno, de la terna remitida por las cámaras de la producción. Como señala Salgado Pesantes ${ }^{19}$, resulta extraño dentro de la experiencia comparada que en la integración de un tribunal constitucional se adopten criterios de representación propios de la defensa de intereses gremiales (organizaciones laborales y productivas) lo que estima poco funcional tratándose de la misión propia del máximo órgano jurisdiccional.

18 Cf. Humberto Nogueira Alcalá: op. cit; pp. 544-545.

19 Cf. Hernán Salgado Pesantes: «La Jurisdicción Constitucional en el Ecuador»; en, La jurisdicción Constitucional en Iberoamérica; op. cit, p. 579. 
El mandato de los vocales del Tribunal Constitucional era originalmente de dos años, extendiéndose a cuatro con la reforma de 1992, con la posibilidad de reelección. Lo corto que sigue siendo este período de mandato, puede conspirar contra la estabilidad e independencia del Tribunal, prestándose más bien al mayor riesgo de manipulación política y partidista de las designaciones. Para ser elegido como Vocal del TC se requiere reunir los mismos requisitos que para ser ministro de la Corte Suprema, es decir: ser ecuatoriano por nacimiento y estar hábil en el goce y ejercicio de sus derechos ciudadanos, ser abogado, tener más de cuarenticinco años y un ejercicio profesional con probidad notoria de la abogacía, judicatura o cátedra universitaria en materia jurídica por no menos de quince años. Aunque anteriormente los Vocales del TC gozaban de las mismas inmunidades que los parlamentarios, ahora este privilegio se limita a la inviolabilidad e irresponsabilidad por sus votos y opiniones.

En el Perú, el Tribunal de Garantías Constitucionales anteriormente existente estuvo conformado por nueve miembros; designados en número de tres respectivamente por el Poder Ejecutivo, el Congreso y la Corte Suprema. Sin embargo, el Tribunal Constitucional instaurado con la Constitución de 1993 está integrado por siete magistrados, todos ellos designados por el Congreso unicameral con el voto favorable de dos tercios del número legal de sus miembros. La función de magistrado del TC es a dedicación exclusiva, excepto el ejercicio de la docencia universitaria. Su mandato es de cinco años y no pueden ser inmediatamente reelegidos.

No se contempla, ni en la Constitución ni en la ley orgánica del TC, la existencia de magistrados suplentes, a pesar que a raíz de la experiencia del TGC tal exigencia resultaba bastante atendible. En efecto, se recuerda que en varios casos del anterior TGC no pudo adoptar sentencia al no reunir los votos exigidos para pronunciarse en acciones de inconstitucionalidad (seis de sus nueve miembros) en parte por vacantes o impedimentos de magistrados que no fueron reemplazados con celeridad. El actual TC, que requiere los votos favorables de seis de sus siete miembros para declarar inconstitucional una ley, afrontó un caso donde cuatro magistrados se abstuvieron de votar imposibilitando la decisión, sin que exista mecanismo (por falta de suplentes) para completar la conformación del tribunal; luego el Congreso destituyó a tres magistrados, sin que se haya designado a los reemplazantes 
a pesar que han transcurrido tres años, lo que impide que el Tribunal pueda ejercer el control de la constitucionalidad de las leyes y determinar que funcione en forma irregular.

Los magistrados del TC peruano gozan del privilegio de antejuicio político ante el Congreso (al igual que algunos otros altos funcionarios) como requisito a cumplirse previamente para su eventual juzgamiento por los delitos de función o infracciones de la Constitución en que incurran. Además disfrutan de inmunidad (similar a los congresistas) para los casos de detención o juzgamiento por delitos comunes, correspondiendo al propio Tribunal Constitucional decidir si autoriza o no el levantamiento de dicha inmunidad. Para ser designado magistrado se requiere ser peruano por nacimiento, ciudadano en ejercicio, tener más de cuarenticinco años; haber sido magistrado de la Corte Suprema o Superior o Fiscal Supremo o Superior por diez años o haber ejercido la abogacía o cátedra universitaria en disciplina jurídica por más de quince años.

Con respecto a la Corte Constitucional de Colombia, el Art. $239^{\circ}$ de la Constitución establece que está integrada por un número impar de magistrados fijado por la ley, procurando que posean diferentes especialidades jurídicas; actualmente su número es de nueve, por decisión de la Ley $\mathrm{N}^{\circ} 5$ de 1992. Los magistrados son designados por el Senado de nueve ternas que le presentan el Presidente de la República (3), la Corte Suprema (3) y el Consejo de Estado (3); se elige un miembro de cada terna, según dispone el Art. $44^{\circ}$ de la Ley Estatutaria de la Administración de Justicia de 1996.

Se exigen iguales requisitos para los cargos de magistrado de la Corte Constitucional, de la Corte Suprema y del Consejo de Estado (Art. $232^{\circ}$ de la Constitución): ser colombiano por nacimiento y ciudadano en ejercicio, ser abogado; no haber sido condenado por sentencia judicial a pena privativa de la libertad, excepto por delitos políticos o culposos; haber ejercido durante diez años cargos en la rama judicial o el Ministerio Público, o la profesión de abogado o cátedra universitaria en disciplina jurídica. No es un requisito para acceder a estos cargos pertenecer a la carrera judicial. No pueden designarse como magistrados de la Corte Constitucional a quienes durante el año precedente a la elección hayan ejercido los cargos de ministro, magistrado de la Corte Suprema o del Consejo de Estado; tampoco el gobierno podrá ofrecer empleo a los magistrados de la Corte durante el ejercicio de sus funcio- 
nes ni en el año siguiente a su cese en el cargo. Estas restricciones e impedimentos parecen positivas para contribuir a la mayor independencia del magistrado de la Corte.

Cada magistrado ejerce el cargo por un período personal de ocho años, sin que proceda la reelección. Goza de inamovilidad en la función en tanto observe buena conducta, tenga rendimiento satisfactorio y no haya llegado a la edad de retiro forzoso de 75 años (Art. $233^{\circ}$ de la Constitución). Los magistrados de la Corte Constitucional gozan de un estatuto personal (similar al de otros altos funcionarios públicos) por el cual los hechos u omisiones que cometan en el ejercicio de sus funciones (aunque ya hayan cesado en éstas) serán juzgadas y sancionadas por el Senado (Art. $174^{\circ}$ de la Constitución). Tratándose de delitos de función o de indignidad por mala conducta, la única sanción que puede imponer el Senado es la destitución del cargo, o la privación temporal o pérdida absoluta de los derechos políticos; en cambio, ante delitos que tengan otras penas, se proseguirá su enjuiciamiento criminal ante la Corte Suprema. Si la acusación es por delitos comunes, el Senado se limitará a decidir si autoriza la formación de causa penal, lo que en caso afirmativo acarreará que el acusado sea puesto a disposición de la Corte Suprema para su juzgamiento

Finalmente, el Tribunal Constitucional de Bolivia está integrado por cinco magistrados, designados por el Congreso (reunión de las Cámaras de Diputados y Senadores) con el voto favorable de dos tercios de los parlamentarios presentes; conjuntamente a ellos se nombran también a los magistrados suplentes. El Ministerio de Justicia, las Facultades de Derecho y los Colegios de Abogados pueden presentar nóminas de candidatos ante el Congreso. Los miembros del TC eligen a su Presidente, con el voto de dos tercios de sus integrantes. Los magistrados suplentes perciben el $50 \%$ de la remuneración de los titulares y acceden a la titularidad sólo en caso de suspensión de aquéllos (por acusación en juicio de responsabilidad o sentencia penal condenatoria ejecutoriada por delito común) supuesto en el que perciben el íntegro del sueldo; sin embargo, en caso de producirse el cese o la vacancia de un magistrado titular, su cargo no será asumido por el suplente sino que el Congreso deberá elegir a un nuevo miembro del Tribunal.

Para ser magistrado del TC se requiere cumplir los requisitos siguientes: ser boliviano por nacimiento, haber cumplido los deberes militares, contar con 35 años cumplidos, estar inscrito en el Registro 
Electoral; tener título de abogado y haber ejercido por un período de diez años, con idoneidad, la judicatura, la profesión de abogado o la cátedra universitaria; no haber sido condenado a pena corporal (salvo rehabilitación del Congreso y no estar incurso en las incompatibilidades establecidas para el cargo. En tal sentido, la condición de magistrado titular o suplente del TC es incompatible con: el ejercicio de cargos públicos o privados, administrativos o sindicales, remunerados o no; con el desempeño de cargos directivos en partidos políticos, asociaciones, fundaciones, colegios profesionales o empresas mercantiles; y con el ejercicio libre de la abogacía. Su función sólo es compatible con el desempeño de la cátedra universitaria.

Cada magistrado tiene un mandato personal de diez años improrrogables, pudiendo ser reelecto luego de transcurrido un tiempo similar al período ejercido en el cargo. Los magistrados del TC tienen la misma prerrogativa del Juicio de Responsabilidad que sus homólogos de la Corte Suprema, proceso de juzgamiento que se realiza ante el Congreso por los delitos que cometan en el ejercicio de sus funciones. Sin embargo, carecen de inmunidad para los delitos comunes.

Encontramos cuestionable el reducido número de magistrados que conforman el Tribunal Constitucional boliviano, sobre todo por lo amplio de las competencias de dicho órgano. Igualmente resulta contraproducente el tratamiento que la Ley del Tribunal Constitucional otorga a los magistrados suplentes pues, a pesar de estar sujetos a las mismas incompatibilidades (laborales u ocupacionales) que los titulares, perciben la mitad de la remuneración y no acceden a la titularidad del cargo ante el cese del titular, a menos que el Congreso los designe como tales. Asimismo se observa como una carencia la ausencia de inmunidad para el enjuiciamiento ante delitos comunes de los magistrados, a diferencia de lo que sucede con sus colegas de la mayoría de tribunales constitucionales.

\subsection{La organización de la corte o tribunal constitucional}

El Tribunal Constitucional de Chile actúa en una sola sala y requiere para su funcionamiento un quórum de la totalidad de sus miembros; en caso de ausencia de un ministro titular, será reemplazado por el abogado integrante de la lista confeccionada para estos efectos, siguiendo el orden de precedencia establecido en ella. Las decisiones del TC 
se adoptan por mayoría simple, teniendo el Presidente voto dirimente en caso de empate. El Presidente del Tribunal es elegido por sus miembros, para un período de dos años que sólo puede ser objeto de reelección para el período inmediato siguiente. El TC elabora una lista de precedencia para acceder al cargo de Presidente; sus funciones se refieren a la conducción administrativa de la institución, el establecimiento del orden para la atención de las causas, presidir y conducir las sesiones y audiencias, disponer la culminación del debate y el paso a votación.

El Tribunal Constitucional del Ecuador actúa en una sala plenaria, contando con un Presidente y un Vicepresidente electos por sus miembros para un período de dos años, con posibilidad de reelección. El Presidente representa al Tribunal, coordina y dirige sus sesiones y audiencias, nombra y remueve al personal y funcionarios del Tribunal, puede nombrar comisiones de asesoría para que ilustren a los magistrados en materias técnicas, dirige la gestión administrativa, establece el orden del día y el reparto de las causas entre los Vocales, y presenta anualmente el informe escrito ante el Congreso sobre la labor desarrollada por la institución.

En la Corte Constitucional de Colombia, las decisiones se adoptan por Sala Plena, con la totalidad de sus miembros, salvo cuando se trata de las sentencias en los procesos de tutela, encomendados a "Salas de Revisión» y de decidir la admisión de causas a trámite, que se realiza por el magistrado sustanciador designado por reparto. El reglamento de la Corte contempla la existencia de nueve Salas de Revisión de Tutela, cada una de ellas presidida por uno de sus nueve magistrados y completada por otros dos, en orden alfabético; de modo que cada magistrado integra simultáneamente tres salas de revisión, una de las cuales preside. Existe una Comisión de Selección de acciones de tutela, compuesta por dos magistrados por el turno de un mes, que califican y determinan cuáles de los procesos llegados a la Corte serán sometidos al conocimiento de ésta.

Para la adopción de sentencias en la Corte Constitucional, se requiere que la parte resolutiva del fallo sea aprobada por la mayoría de los magistrados, mientras que los fundamentos de la sentencia pueden serlo sólo por la mayoría de los asistentes. La Corte elige a un Presidente y un Vicepresidente, correspondiendo al primero presidir las sesiones de Sala Plena, ser el nexo de comunicación entre la Corte y otros órganos del Estado y la sociedad, así como ejercer la dirección de 
la administración y el funcionamiento institucional. El Vicepresidente reemplaza al Presidente en caso de ausencia. El mandato de ambos tiene una duración de un año.

En cuanto al Tribunal Constitucional del Perú, sólo actúa y resuelve en reunión plenaria de sus siete miembros; se ha cuestionado que no tenga previsto en su ley orgánica la conformación de salas para la decisión (con mayor celeridad) de las acciones de hábeas corpus, amparo, hábeas data o de cumplimiento llegadas en recurso extraordinario tras su desestimación en sede judicial. El quórum original establecido para el funcionamiento del TC es de seis miembros, adoptando decisión por mayoría simple, salvo cuando se trata de la admisión de acciones de inconstitucionalidad o de la sentencia que declara inconstitucional una norma de rango legal, supuestos en los que se exigen seis votos conformes. Actualmente, tras la arbitraria destitución por el Congreso de tres magistrados, el quórum se rebajó a cuatro, pero no para las acciones de inconstitucionalidad, no siendo posible que el Tribunal pueda conocer de estas acciones ni de los conflictos de competencia. El Tribunal cuenta con un Presidente y un Vicepresidente, elegidos en votación secreta por sus miembros para un período de dos años.

El Tribunal Constitucional de Bolivia adopta decisiones en Sala Plena conformada por la totalidad de sus cinco miembros. Existe una Comisión de Admisión integrada por tres magistrados, que desempenarán esta función en forma rotativa y obligatoria, sin que ninguno lo haga por más de dos veces consecutivas por turno. El Tribunal elige a su Presidente, disponiendo la ley de reforma constitucional que para ser elegido se requería alcanzar el voto favorable de dos tercios de los magistrados, cifra verdaderamente alta en especial atendiendo al reducido número de integrantes del TC. La vigente Ley $\mathrm{N}^{\circ} 1836$, del 19 de marzo de 1998, ha dispuesto -más acertadamente- que su elección se hará por la mayoría de votos de sus magistrados, en votación oral y nominal; el mandato del Presidente es de cinco años, pudiendo ser reelegido.

El Presidente dirige y representa al Tribunal Constitucional, vela por el correcto desempeño de las funciones institucionales, ejerce las potestades disciplinarias sobre el personal, salvo las que competen al Consejo de la Judicatura, y adopta las resoluciones administrativas que no son potestad del Pleno. Las resoluciones que adopta el TC son de tres tipos: sentencias, cuando resuelven sobre demandas y recursos; 
declaraciones constitucionales, cuando absuelven las consultas; y autos, cuando se pronuncian sobre la admisión, rechazo, desistimiento o caducidad de la acción. Complementando lo dispuesto por la Constitución y la Ley $N^{\circ} 1836$ del Tribunal Constitucional, este órgano ha aprobado (por Acuerdo 03/99, del 2 de febrero de 1999) el Reglamento de Procedimientos Constitucionales, que norma y regula su actuación en el conocimiento y trámite de las acciones y materias de su competencia.

\subsection{Principales competencias y atribuciones}

El Tribunal Constitucional del Ecuador, tras las reformas constitucionales de 1996 y 1998, así como de la Ley de Control Constitucional de junio de 1997, es competente para conocer de las materias siguientes:

- Resolver las demandas de inconstitucionalidad, por razones de fondo o forma, que se promuevan contra leyes orgánicas u ordinarias, decretos-leyes, decretos, reglamentos u ordenanzas, emitidas por órganos del Estado; así como suspender total o parcialmente sus efectos.

- Resolver sobre la inconstitucionalidad de los actos administrativos dictados por cualquier autoridad pública, acarreando la declaratoria de su inconstitucionalidad la revocatoria del acto.

- Resolver sobre las resoluciones que deniegan las acciones de hábeas corpus, hábeas data y amparo; así como las apelaciones o consultas generadas en las acciones de amparo.

- Dictaminar sobre las objeciones de inconstitucionalidad que haya formulado el Presidente de la República en el proceso de formación de las leyes.

- Emitir dictamen sobre la constitucionalidad de tratados y convenios internacionales, antes de su aprobación por el Congreso.

- Dirimir conflictos de competencias o de atribuciones asignadas por la Constitución.

- Conocer de los informes que le presenten las Salas de la Corte Suprema o los Tribunales de última instancia con respecto a las sentencias que hayan dictado declarando la inconstitucionalidad, a ser remitidos dentro de los treinta días de ejecutoriadas. El Tribunal 
Constitucional resolverá, con carácter de obligatoriedad general, sobre la inaplicabilidad de un precepto legal si fuere contrario a la Constitución, aunque esta resolución no tendrá efecto sobre el fallo dictado en el proceso judicial.

Con respecto al Tribunal Constitucional de Chile, de conformidad con el artículo $82^{\circ}$ de la Constitución, es competente para ejercer las funciones siguientes:

a) Control de la constitucionalidad de normas:

- Realizar obligatoriamente el control preventivo de constitucionalidad de los proyectos de leyes orgánicas y de leyes interpretativas de la Constitución.

- Resolver, con carácter previo a la aprobación de las normas, sobre las cuestiones de inconstitucionalidad que se susciten durante la tramitación de los proyectos de ley o de reforma constitucional y de los tratados sometidos a la aprobación del Congreso.

- Conocer sobre las cuestiones que se promuevan respecto de la constitucionalidad de los decretos con fuerza de ley, luego de promulgados.

b) Control facultativo (a instancia de determinadas autoridades) de la potestad normativa y reglamentaria ejercida por el Gobierno:

- Pronunciarse sobre la constitucionalidad de la convocatoria a plebiscito por el Presidente de la República, sin perjuicio de las atribuciones del Tribunal Calificador de Elecciones en la materia.

- Resolver sobre los reclamos que se presenten por la negativa del Presidente a promulgar una ley, cuando promulgue un texto distinto o dicte un decreto inconstitucional.

- Resolver sobre los decretos gubernamentales que la Contraloría haya considerado inconstitucionales.

- Resolver sobre los decretos supremos reglamentarios dictados infringiendo la reserva legal material establecida a favor del legislador.

c) Declarar la inconstitucionalidad de organizaciones, movimientos o partidos políticos.

d) Emitir informe ante el Senado cuando éste debe resolver sobre la declaración de impedimento o inhabilidad del Presidente de la República; así como pronunciarse sobre las causales de impedimento, incompatibilidades y cesación en el cargo de los parlamentarios; y 
resolver sobre las inhabilidades constitucionales o legales que afectan a las personas designadas para el cargo de Ministro de Estado, para permanecer en dicho cargo o para desempeñar simultáneamente otras funciones.

El número de competencias del Tribunal Constitucional Peruano resulta, en comparación con el de otros órganos similares, bastante reducido. Así, le corresponde conocer de:

- Acciones de inconstitucionalidad (de carácter directo y abstracto) que se interpongan contra leyes, decretos legislativos, decretos de urgencia, tratados internacionales, Reglamento del Congreso, normas regionales de carácter general y ordenanzas municipales; cuando por razones de forma o de fondo vulneran la Constitución.

- Resolver, en última y definitiva instancia, las acciones de hábeas corpus, amparo, hábeas data y de cumplimiento; cuando hayan sido previamente desestimadas en el Poder Judicial.

- Resolver los conflictos de competencia o atribuciones que se susciten entre los órganos de gobierno territorial del Estado: Gobierno Central con gobiernos locales o regionales, o estos últimos entre sí; como de los que se generen entre los poderes del Estado entre sí o de éstos con los órganos constitucionales autónomos (Jurado $\mathrm{Na}$ cional de Elecciones, Consejo Nacional de la Magistratura, Ministerio Público, Contraloría, etc.) o de éstos entre sí.

La Corte Constitucional de Colombia, según dispone el Art. $241^{\circ}$ de la Constitución, es competente para conocer de los asuntos siguientes:

a) En cuanto al control de la constitucionalidad de los procesos de reforma constitucional, de referéndum y reforma legislativa:

- Demandas de inconstitucionalidad promovidas por los ciudadanos contra los actos de reforma de la Constitución, cualquiera que sea su origen, exclusivamente por vicios de procedimiento en su formación.

- Decidir, con anterioridad al pronunciamiento popular, sobre la constitucionalidad de la convocatoria a un referéndum o asamblea constituyente para reformar la Constitución, pero sólo por vicios de procedimiento en su formación. 
- Constitucionalidad de referéndum sobre leyes y de consultas populares y plebiscitos de nivel nacional, en este último caso sólo por vicios de procedimiento en la convocatoria y realización.

b) En cuanto al control de constitucionalidad de las normas:

- Demandas de inconstitucionalidad promovidos por los ciudadanos contra leyes y decretos con fuerza de ley (facultades extraordinarias y plan nacional de inversiones públicas) dictados por el Gobierno, sea por razones de contenido como de vicios de procedimiento en su formación.

- Decidir definitivamente sobre la constitucionalidad de los decretos legislativos dictados por el Gobierno en los casos de estado de guerra exterior, de conmoción interior o de estado de emergencia.

c) En cuanto al control preventivo de la constitucionalidad de proyectos de normas:

- Resolver acerca de los proyectos de ley cuya constitucionalidad haya sido objetada por el Gobierno y cuando el Congreso haya resuelto insistir en su contenido ${ }^{20}$; así como de los proyectos de leyes estatutarios $^{21}$, por razones de contenido y de procedimiento.

- Decidir sobre la exequibilidad de los tratados internacionales y las leyes que los aprueban, antes de su ratificación por el Gobierno. Cuando algunas normas de los tratados sean declaradas inexequibles por la Corte, el Presidente sólo podrá ratificarlos con reserva de tales normas.

d) En cuanto a la protección de los derechos constitucionales, la Corte podrá revisar las resoluciones judiciales dictadas en los procesos de

20 En tal supuesto, el proyecto se remite a la Corte para que efectúe el análisis de su constitucionalidad y resuelva dentro de los seis días siguientes. Si la Corte confirma la constitucionalidad de la norma, el Presidente tiene que promulgarla; si la cuestiona, el proyecto se archiva; si el proyecto es encontrado parcialmente inconstitucional por la Corte, volverá a la cámara de origen para que ésta introduzca los ajustes necesarios, remitiéndose luego nuevamente para su revisión definitiva.

21 Las leyes estatutarias, a diferencia de las leyes ordinarias, deben aprobarse con el voto de la mayoría absoluta de los miembros del Congreso, y tramitarse dentro de una misma legislatura. Están reservadas a regular las materias siguientes: derechos y deberes fundamentales de las personas, así como los recursos destinados a su protección; administración de justicia; organización y régimen de los partidos políticos, estatuto de la oposición y funciones electorales; instituciones y mecanismos de participación ciudadana; estados de excepción. 
tutela. Todas las sentencias judiciales finales de acciones de tutela, sean o no impugnadas, se elevarán necesariamente ante la Corte Constitucional para que ésta determine discrecionalmente cuáles selecciona para su revisión.

El Tribunal Constitucional de Bolivia cuenta con una amplia gama de competencias y atribuciones, correspondiéndole (según los arts. $120^{\circ}$ de la Constitución y $7^{\circ}$ de la Ley $\mathrm{N}^{\circ} 1836$ del TC) conocer de:

a) En instancia única, de los recursos directos o abstractos de inconstitucionalidad promovidos contra leyes, decretos, así como de resoluciones de carácter general no vinculadas a procesos judiciales o administrativos.

b) Recursos indirectos o incidentales de inconstitucionalidad contra leyes, decretos y resoluciones generales, promovidos en el marco de un proceso judicial o administrativo.

c) Recursos de inconstitucionalidad contra tributos, impuestos, tasas, patentes, derechos o contribuciones de cualquier naturaleza creados, suprimidos o modificados en contravención de la Constitución, a ser promovido por el afectado.

d) Consultas acerca de la constitucionalidad de tratados y convenios internacionales, suscritos con otros Estados u organismos internacionales, antes de su aprobación.

e) Impugnaciones del Poder Ejecutivo de las resoluciones camarales, prefecturales o municipales contrarias a la Constitución.

f) Recursos directos de nulidad contra los actos o resoluciones de quienes usurpan funciones o jurisdicción que no les competen ni emanan de la ley.

g) Recursos contra resoluciones del Poder Legislativo o de una de sus Cámaras que afectan derechos o garantías de cualquier persona.

h) Revisión de las resoluciones judiciales recaídas en las acciones de amparo y de hábeas corpus.

i) Conflictos de competencia y controversias que se susciten entre los Poderes Públicos, la Corte Nacional Electoral, los departamentos y los municipios.

j) Las consultas formuladas por el Presidente de la República, los Presidentes del Congreso o de la Corte Suprema, sobre la constitucionalidad de proyectos de ley, de decretos o resoluciones; siendo la de- 
cisión del Tribunal obligatoria para el órgano que formula la consulta.

k) Demandas contra los procedimientos de reforma constitucional que no observen el trámite o requisitos establecidos en la Constitución.

\subsection{El control de constitucionalidad de las normas}

El Tribunal Constitucional de Chile, su principal función de control de la constitucionalidad de normas está referida a la revisión obligatoria que, con carácter previo, debe realizar de los proyectos de leyes orgánicas y de leyes interpretativas de algún precepto de la Constitución aprobados por el Congreso, antes de su promulgación por el Presidente de la República. Para este efecto, el Presidente de la Cámara parlamentaria donde se origina el proyecto, dentro de los cinco días posteriores a que quedó agotado el trámite parlamentario, remitirá el proyecto aprobado al Tribunal Constitucional. Si durante la tramitación de proyectos de ley se suscita alguna objeción de su constitucionalidad o de algunos de sus artículos, se remitirá también las actas de las sesiones donde se debatió este aspecto.

Realizada la revisión del proyecto por el TC, éste se pronunciará acerca de su constitucionalidad. Si lo declara constitucional, comunicará esta decisión al Presidente de la Cámara de origen. Cuando se haya suscitado controversia en el debate parlamentario sobre la constitucionalidad de algún precepto del proyecto, el Tribunal deberá emitir resolución fundamentada respecto del carácter constitucional o inconstitucional de la norma. Una vez declarada por el TC la conformidad constitucional de un proyecto o norma, el punto ya no podrá ser nuevamente planteado. En cambio, cuando la resolución del Tribunal estime inconstitucional algún precepto, el Congreso remitirá al Presidente de la República el proyecto para su promulgación excluyendo tales preceptos.

El TC chileno ejerce también control facultativo de la constitucionalidad de los proyectos de ley, de reforma constitucional o de tratados sometidos a aprobación del Congreso, siempre que se haya suscitado durante la tramitación alguna objeción de su constitucionalidad, pero antes de la promulgación por el Presidente de la República. El requerimiento sólo podrá presentarse ante el Tribunal por el Presidente de la República, el Presidente de una Cámara del Congreso o 
por la cuarta parte de los parlamentarios en ejercicio de una Cámara. El Tribunal comunicará al Presidente de la República el requerimiento recibido, para que se abstenga (durante diez días prorrogables) de promulgar la norma o la parte impugnada de ésta hasta que el punto sea resuelto; pondrá el asunto en conocimiento de los órganos interesados, quienes dispondrán de cinco días para formular sus observaciones. Vencido este término, resolverá sobre el tema controvertido, comunicando su sentencia a las instancias recurrentes y, en su caso, al Presidente de la República y a la Corte Suprema para los fines pertinentes.

Con respecto al control de la constitucionalidad de los decretos con fuerza de ley dictados por el Presidente de la República, por delegación del parlamento, éste sólo será previo si la objeción fue planteada por la Contraloría y el Presidente decide someter la controversia ante el Tribunal Constitucional; el control será posterior, en cambio, si dentro de los treinta días ulteriores a la vigencia de los decretos son objetados ante el TC por cualquiera de las Cámaras o por una cuarta parte de sus integrantes. En el caso de los decretos que invaden la reserva legal material establecida en la Constitución para el legislador, sólo pueden ser objetados por las Cámaras del Congreso.

Conviene resaltar que los ciudadanos no tienen ninguna participación ante el Tribunal Constitucional chileno, sea con iniciativa o durante el proceso instaurado, en los diversos mecanismos de control de constitucionalidad de las normas. Asimismo debe recordarse que el control concreto acerca de la constitucionalidad de normas legales vigentes, es ejercido de forma exclusiva y uconcentrada» por la Corte Suprema a través del recurso de inaplicabilidad. Si la Corte estima inconstitucional la ley objetada o un precepto de ésta, su sentencia se remitirá al tribunal inferior para que inaplique la norma en el caso concreto, conservando su vigencia y obligatoriedad general ${ }^{22}$.

En el caso de Ecuador, el Tribunal Constitucional conoce de las acciones de inconstitucionalidad que se promueva contra leyes, decretos-leyes, decretos, reglamentos $\mathrm{u}$ ordenanzas, tanto por razones de forma

22 Para apreciar las características de este procedimiento y la actuación de la Corte Suprema, puede verse el ya citado trabajo de Gastón Gómez, pp. 146-156. Igualmente su trabajo: El recurso de inaplicabilidad; Centro de Investigaciones de la Facultad de Derecho de la Universidad Diego Portales; serie Informes de Investigación $\mathrm{N}^{\circ}$ 4, Año 1; Santiago de Chile; Nov. 1999. 
como de fondo. Están legitimados para interponer esta acción el Presidente de la República, el Congreso (previa resolución mayoritaria de sus miembros), la Corte Suprema (por acuerdo del Pleno), mil ciudadanos, y también cualquier persona, aunque en este último caso sólo previo informe de la Defensoría del Pueblo acerca de su procedencia. Es curioso que no se reconozca legitimación a un número determinado de congresistas, sino exclusivamente a una mayoría parlamentaria. El Tribunal tendrá tres días para calificar la demanda y, de admitirla, correrá traslado por quince días al órgano que expidió la norma cuestionada, a fin de que la conteste. A pedido de parte, el TC podrá citar a una audiencia pública para que las partes realicen una exposición oral de treinta minutos cada una.

La resolución del Tribunal deberá dictarse dentro de los treinta días hábiles siguientes al vencimiento del plazo de contestación de la demanda o de la celebración de la audiencia. La sentencia del TC declarando la inconstitucionalidad de la norma cuestionada, acarreará el cese de su vigencia desde la publicación de la resolución en el diario oficial. Dicha sentencia no afectará las relaciones jurídicas surgidas al amparo de la norma ni antes de su declaración de inconstitucionalidad. Cabe recordar que hasta antes de la reforma constitucional de 1996, la sentencias del TC que declaraban inconstitucional una norma sólo suspendían temporalmente su vigencia, estando sujetas a la decisión definitiva, de alcance general, que adopte el Congreso (en una primera etapa) o la Sala Constitucional de la Corte Suprema (en una etapa más reciente). En la actualidad, la declaración de inconstitucionalidad de una ley o norma por el TC tiene efecto general, es definitiva e irrecurrible.

El Tribunal también es competente para ejercer el control previo de la constitucionalidad de una ley aprobada por el Congreso que sea objetada por el Presidente de la República. En tal supuesto, y siempre que lo aprueben la mayoría de congresistas o el pleno de la comisión legislativa dentro de los diez días de recibida la objeción, se remitirá el proyecto de ley al Tribunal, quien deberá resolver en un término similar de diez días. Si la objeción de inconstitucionalidad es desestimada por el TC, ordenará la publicación de la ley en el registro oficial. Asimismo, conviene reiterar que cuando una Sala de la Corte Suprema o tribunal de última instancia declaren la inconstitucionalidad de una norma, remitirán un informe al Tribunal Constitucional (dentro de los 
treinta días de ejecutoriada la sentencia) para que éste resuelva con carácter obligatorio y general sobre la inaplicabilidad futura del precepto legal considerado inconstitucional, aunque su decisión no afectará lo resuelto en el caso concreto por el órgano judicial.

Con respecto al Tribunal Constitucional del Perú, conoce de las acciones de inconstitucionalidad que se interpongan contra leyes, decretos legislativos, decretos de urgencia, tratados, reglamentos del Congreso, normas regionales de carácter general u ordenanzas municipales. Están legitimados para interponer esta acción: el Presidente de la República, el Fiscal de la Nación, el Defensor del Pueblo, el veinticinco por ciento de los congresistas, cinco mil ciudadanos (salvo cuando se impugnen ordenanzas municipales, donde se exigirá el 1\% de ciudadanos del ámbito territorial, siempre que no excedan de cinco mil); también pueden hacerlo los Presidentes de la Región (con acuerdo del Consejo Regional) y los alcaldes (con acuerdo del Concejo Municipal) pero en asuntos de su competencia; finalmente le compete a los Colegios Profesionales, en asuntos de su especialidad ${ }^{23}$.

La acción de inconstitucionalidad debe promoverse dentro de los seis meses de vigencia de la norma. El TC requiere del voto favorable de seis de sus siete magistrados para declarar su inadmisibilidad; igual votación se requiere para adoptar la sentencia declaratoria de inconstitucionalidad. De la demanda se corre traslado por treinta días a la autoridad que dictó la norma En caso de no alcanzarse el número de votos exigidos, y a pesar que pudiera existir una mayoría absoluta de cuatro o cinco magistrados favorables a la declaratoria de inconstitucionalidad, el artículo $4^{\circ}$ de la Ley Orgánica del Tribunal Constitucional manda a éste dictar sentencia desestimando la acción y declarando la constitucionalidad de la norma, la misma que no podrá ser objetada en un nuevo proceso. Esta exigencia de seis de siete votos conformes, fue introducida por el Congreso con la clara intención de limitar severa-

23 Merece ser destacada como una positiva novedad introducida por la Constitución de 1993, con respecto a la Carta de 1979, la ampliación de la legitimación para interponer la acción de inconstitucionalidad, reduciendo de cincuenta mil a cinco mil el número de ciudadanos requeridos y otorgando esta potestad también a los Colegios Profesionales; contemplado así alguna forma de participación ciudadana y popular en el control (de carácter abstracto y efecto general) de la constitucionalidad de las normas de rango legal. 
mente la viabilidad de la declaratoria de inconstitucionalidad; supedita, de manera cuestionable e irracional, la voluntad de la mayoría del Tribunal a una minoría de dos magistrados, siendo una exigencia sin precedentes en el derecho comparado.

La sentencia del Tribunal que declara inconstitucional una norma tiene alcance general y conlleva su derogación a partir del día siguiente de la publicación del fallo en el diario oficial. La sentencia no tiene efectos retroactivos, salvo en materia penal (en tanto resulte más benigna); cuando la inconstitucionalidad se refiere a una norma tributaria, el Tribunal podrá determinar si los efectos del fallo son retroactivos. La declaratoria de inconstitucionalidad de una ley constituye cosa juzgada pero no permite revivir procesos judiciales fenecidos donde se aplicó la norma derogada; por su derogación tampoco recobran vigencia las normas que ella pudo haber derogado. Cabe indicar que los jueces no podrán declarar inaplicable por inconstitucional, en un caso concreto, una norma cuya constitucionalidad haya sido confirmada por el Tribunal (Art. $39^{\circ}$ de la LOTC). Además, la primera de las Disposiciones Generales de la Ley Orgánica del TC, establece que los jueces y tribunales judiciales deberán interpretar y aplicar las leyes y normas según los preceptos y principios constitucionales conforme a la interpretación que de ellos haga el Tribunal Constitucional en sus resoluciones de todo tipo de procesos.

La Corte Constitucional de Colombia, ejerce el control de la constitucionalidad de las normas por diversos procedimientos: a) acción de inconstitucionalidad (control abstracto); b) excepción de inconstitucionalidad (control concreto); c) control previo o preventivo, con respecto a los proyectos de leyes estatutarias y a la revisión de las objeciones presidenciales a la constitucionalidad de proyectos de ley; d) control de oficio de los tratados internacionales y de las leyes que los aprueban, así como de los decretos legislativos dictados por el Gobierno en los estados de excepción ${ }^{24}$.

La acción de inconstitucionalidad es una acción popular que puede ser interpuesta por cualquier ciudadano contra leyes y decretos con fuerza de ley. La Corte ha establecido que no puede ser promovida por personas jurídicas (sentencia C-003 de 1993) pero sí por los funciona-

24 Cf. Eduardo Cifuentes Muñoz: "La justicia constitucional en Colombia»; en, Anuario Iberoamericano de Justicia Constitucional 1997; pp. 74-80. 
rios públicos en su condición de ciudadanos, así como por el Defensor del Pueblo (Auto 011 de 1995) ${ }^{25}$. Se trata de un control abstracto, porque la constitucionalidad de la norma se efectúa sin estar referida a ningún caso de aplicación concreta, por lo que la sentencia de la Corte tiene carácter general y efecto erga omnes. El procedimiento establecido para la acción de inconstitucionalidad (previsto en el Decreto $\mathrm{N}^{\circ}$ 2067 de 1991) se aplica también, complementaria y supletoriamente, a la tramitación de los restantes procesos especiales de control de constitucionalidad de normas, en lo que no esté expresamente regulado para éstos.

Si bien la demanda de inconstitucionalidad debe contener diversos requisitos, y el Art. $6^{\circ}$ del Decreto $N^{\circ} 2067$ de 1991 prevé los supuestos de omisión o transgresión de éstos que ameritan la necesidad de subsanación o el rechazo de la acción respectivamente, la Corte ha interpretado que -por el carácter popular y público de esta acción- los mismos deben apreciarse sin demasiada rigurosidad formal. La demanda se remite al magistrado sustanciador, quien deberá pronunciarse sobre su admisión en el término de diez días. Admitida la acción, se correrá traslado de la demanda al Procurador General de la Nación por treinta días; el auto admisorio mandará también que se publique la lista de las normas acusadas de inconstitucionalidad, para que durante el plazo de diez días cualquier ciudadano pueda impugnarlas o defenderlas. Vencido el término del traslado, el magistrado sustanciador deberá elaborar y presentar al Pleno de la Corte (en el término de treinta días) su ponencia con la propuesta de sentencia; la Corte deberá resolver dentro de los sesenta días siguientes.

Las sentencias que emite la Corte en materia del control constitucional de las normas tienen carácter de cosa juzgada, conforme lo dispone el Art. $243^{\circ}$ de la Constitución Política. Agrega dicho precepto que «ninguna autoridad podrá reproducir el contenido material del acto jurídico declarado inexequible por razones de fondo, mientras subsistan en la Carta las disposiciones que sirvieron para hacer la confrontación entre la norma ordinaria y la Constitución". Las sentencias se adoptan por mayoría de los votos de los magistrados que conforman la Corte, mientras que los fundamentos del fallo pueden aprobarse con el voto favorable de la mayoría de los asistentes. 
Cabe anotar que el Decreto No 2067 de 1991 (dictado por el Gobierno en virtud de una habilitación de la propia Constitución) establecía en su Art. $21^{\circ}$, segundo párrafo, que «los fallos de la Corte sólo tendrán efecto hacia el futuro, salvo para garantizar el principio de favorabilidad en materia penal, policiva y disciplinaria, y en el caso previsto en el artículo $149^{\circ}$ de la Constitución" (actos emitidos irregularmente por miembros del Congreso). Sin embargo, la Corte declaró inconstitucional dicha norma (sentencia C-133 de 1993) por considerar que la potestad conferida al Gobierno, en una disposición transitoria de la Constitución, se limitaba a autorizarlo para regular los juicios y actuaciones ante la Corte pero no a determinar los efectos de su sentencia, aspecto que concernía únicamente al propio tribunal constitucional.

Es así que actualmente en la Ley Estatutaria de la Administración de Justicia (Ley $N^{\circ} 270$ de 1996) el artículo $45^{\circ}$ establece que «las sentencias que profiera la Corte Constitucional sobre los actos sujetos a su control en los términos del artículo $241^{\circ}$ de la Constitución Política, tienen efecto hacia el futuro a menos que la Corte resuelva lo contrario». Conforme precisa el magistrado de la Corte Eduardo Cifuentes ${ }^{26}$, por regla general la Corte confiere a sus fallos efectos hacia el futuro, salvo cuando se trata de impedir la consolidación de actos arbitrarios, supuesto en el cual ha conferido a la sentencia efectos retroactivos. Agrega el artículo $48^{\circ}$ inciso $1^{\circ}$ de la referida Ley Estatutaria, que las sentencias de la Corte recaídas en procesos de control constitucional de normas legales (por acción, control previo o revisión de oficio) tendrán alcance erga omnes y obligatoriedad de cumplimiento sólo en su parte resolutiva, mientras que la parte de motivación constituirá criterio auxiliar para la actividad judicial y la aplicación de las normas de derecho.

El Tribunal Constitucional de Bolivia, controla la constitucionalidad de las leyes, decretos y resoluciones generales, tanto con carácter abstracto, a través del recurso directo de inconstitucionalidad, como de manera específica, mediante el recurso indirecto o incidental de inconstitucionalidad en un proceso judicial o administrativo. También lo hace en forma previa o preventiva por medio de las consultas sobre la constitucionalidad de tratados y convenios internacionales como de proyectos de ley. 
El recurso directo de inconstitucionalidad, dirigido al control abstracto de leyes, decretos y resoluciones de carácter general, puede ser interpuesto por el Presidente de la República, cualquier senador o diputado, el Fiscal General de la Nación y el Defensor del Pueblo; están excluidos de esta potestad los ciudadanos, las organizaciones sociales y el propio Poder Judicial. La demanda se somete a la Comisión de Admisión que, de admitirla, corre traslado al órgano que dictó la norma por un plazo de quince días; verificado dicho término, el Tribunal Constitucional tiene treinta días para dictar sentencia, que se adopta con el voto de la mayoría de sus miembros. La sentencia que declara inconstitucional la norma cuestionada acarrea su derogación, mientras que si la inconstitucionalidad es parcial sólo deroga los artículos afectados; el Tribunal puede también resolver la inconstitucionalidad de otras normas conexas a la demandada, con similares efectos derogatorios. En cambio, si el TC estima como constitucional la norma objetada, ésta ya no podrá ser nuevamente impugnada.

$\mathrm{El}$ recurso indirecto o incidental de inconstitucionalidad puede ser promovido en cualquier proceso judicial o administrativo, sea a petición de parte o de oficio, por una sola vez y en cualquier instancia del proceso (salvo en la fase de ejecución de sentencia) cuando la decisión a adoptarse en éste depende de la aplicación de una norma cuya constitucionalidad debe ser previamente esclarecida. Interpuesto el recurso, la autoridad que conoce del proceso correrá traslado a la otra parte por tres días; con respuesta o sin ella, y en igual plazo, expedirá resolución rechazando el incidente (si resulta manifiestamente infundado) o admitiéndolo. En ambos casos el asunto se eleva al Tribunal Constitucional, aunque en el primero se eleva (de oficio) en consulta la resolución denegatoria; ello no paraliza el proceso principal, que podrá continuar hasta el estado de pronunciar sentencia. Tras su revisión por la Comisión de Admisión, el TC debe resolver el caso dentro de los treinta días, siendo su decisión obligatoria para la resolución del caso concreto por el órgano judicial ${ }^{27}$.

27 El Art. $65^{\circ}$ de la Ley del Tribunal Constitucional N¹836 (del 19 de marzo de 1998) atribuye expresamente a la sentencia en el recurso indirecto o incidental de inconstitucionalidad los mismos efectos derogatorios de la norma cuestionada contemplados en el Art. $58^{\circ}$ de la misma ley, referido a la sentencia del recurso directo de inconstitucionalidad. Tal asimilación resulta seriamente errada e impertinente, pues 
Debemos reiterar que si bien el Art. $228^{\circ}$ de la Constitución (que no fue incluido en la reforma de 1994) establece la supremacía de la norma constitucional y manda a todo tribunal, juez y autoridad aplicarla con preferencia sobre cualquier ley; dicha norma parece haber quedado algo "descolgada" desde el momento en que la Ley del Tribunal Constitucional encomienda a éste la resolución de los recursos indirectos o incidentales de inconstitucionalidad que se susciten en cualquier proceso judicial. Coincidimos con Fernández $\mathrm{Segado}^{28}$ en que pueden generarse ciertos conflictos acerca de los alcances de este precepto que, de no dársele una interpretación adecuada y sistemática, acarrearían confusión en cuanto a las competencias del Poder Judicial y el TC en materia del control de la constitucionalidad de las normas. Consideramos que la potestad de ejercer el "control difuso" por el órgano judicial ordinario, emanada del Art. $228^{\circ}$ de la Constitución, ya no supondría un proceso autónomo, paralelo o separado; quedando más bien sujeto al sistema de control incidental que atribuye al Tribunal Constitucional la apreciación y decisión definitiva sobre la constitucionalidad o inconstitucionalidad de una norma.

\subsection{La protección de los derechos constitucionales}

En el Ecuador, la protección de los derechos constitucionales se realiza mediante las acciones de hábeas corpus, amparo y hábeas data; que, de ser denegadas en sede judicial, pueden ser recurridas ante el Tribunal Constitucional. El hábeas corpus procede para proteger la libertad personal frente a las detenciones arbitrarias, teniendo en el Ecuador la particularidad que se presenta y resuelve ante el Alcalde Municipal, quien mandará la exhibición del detenido, analizará el fundamento de la detención y dispondrá, si corresponde, su inmediata libertad y la destitución del funcionario infractor. El hábeas corpus también proce-

es bien sabido que en el proceso de control abstracto la sentencia tiene efectos generales y acarrea la derogación de la norma inconstitucional, mientras que en el recurso incidental sólo inaplica y no deroga la norma cuya inconstitucionalidad se declara, y que sus alcances se extienden únicamente a las partes del proceso concreto.

28 Cf. Francisco Fernández Segado: «La Jurisdicción Constitucional en la reforma de la Constitución de Bolivia de 1994»; en, La Jurisdicción Constitucional en Iberoamérica; p. 369. 
de cuando la detención se motiva en la acción u omisión judicial; si se verifica que el detenido está privado de la libertad sin mediar auto de sobreseimiento, de apertura de plenario o de sentencia dentro de los términos temporales previstos en la ley, el alcalde dispondrá su liberación.

El amparo está previsto para la protección de los derechos reconocidos en la Constitución y los pactos internacionales de derechos humanos, frente a los actos u omisiones de autoridades públicas que hayan causado, causen o puedan causarles un daño inminente e irreparable. La acción podrá ser interpuesta por el afectado, su apoderado o el Defensor del Pueblo; en casos de defensa del medio ambiente, la podrá promover cualquier persona natural o jurídica. Se substanciará ante el juez civil aunque, en casos de emergencia, podrá presentarse ante juez o tribunal en día no hábil y fuera de horario. Dentro de las veinticuatro horas de recibida la acción, el juez citará a audiencia pública, a efectuarse dentro de las veinticuatro horas siguientes. El juez podrá disponer la suspensión provisional del acto lesivo reclamado y la sentencia se dictará dentro de las cuarentiocho horas posteriores a la audiencia.

Si la sentencia declara fundada la acción, se ejecutará inmediatamente y dispondrá la suspensión definitiva del acto cuestionado. Esta sentencia favorable al actor será elevada en consulta ante el Tribunal, al igual que si se produce la apelación de una sentencia denegatoria de la acción. El proceso será revisado por una sala del Tribunal Constitucional, que deberá dictar sentencia dentro de los diez días siguientes. La sentencia será de obligatorio cumplimiento por la autoridad, pudiendo emplearse el uso de la fuerza pública para asegurar su ejecución y el de la medida de suspensión. No podrá promoverse una nueva acción de amparo sobre la misma materia o motivo.

Con respecto al hábeas data, podrá ser interpuesto por personas naturales o jurídicas, nacionales o extranjeras, para conocer la información que sobre sí mismas o sus bienes consta en entidades públicas o personas privadas, así como para saber el uso que se ha dado o se piensa dar a tal información. No será admisible esta acción cuando vulnere el sigilo profesional, pueda obstruir la acción de la justicia o se refiera a documentos reservados por razones de seguridad nacional; tampoco podrá solicitarse la eliminación de la información que, por mandato legal, deba mantenerse archivada en registros públicos o privados. Fuera de estos casos, el interesado puede solicitar también la rectificación, 
eliminación o prohibición de difusión a terceros de ciertos datos. El juez citará a audiencia, que se verificará dentro de los ocho días, debiendo dictar sentencia dentro de los dos días posteriores a ella. La sentencia denegatoria de la acción podrá ser apelada, dentro de los ocho días, ante el Tribunal Constitucional.

En Colombia, la acción de tutela es el proceso esencial para la protección de los derechos constitucionales. El artículo $86^{\circ}$ de la Constitución define a la acción de Tutela como el procedimiento preferente y sumario por el cual cualquier persona (o quien actúa en su nombre) reclama ante los jueces, en todo momento y lugar, la inmediata protección de sus derechos constitucionales fundamentales, cuando éstos sean objeto de vulneración o amenaza por la acción u omisión de cualquier autoridad pública. Dicha norma remite a la ley la determinación de los casos en que también resulte procedente la acción de tutela contra particulares encargados de la prestación de servicios públicos, o cuya conducta afecte grave y directamente el interés colectivo, o respecto de quienes el solicitante se halle en estado de subordinación o indefensión.

La acción de tutela tiene carácter subsidiario, y no alternativo, pues su ejercicio se justifica sólo cuando el afectado no disponga de otro medio de defensa judicial, a menos que la acción se utilice como mecanismo transitorio para evitar un perjuicio irremediable ${ }^{29}$. Señala el referido Art. $86^{\circ}$ de la Constitución que en ningún caso podrán transcurrir más de diez días entre la interposición de una acción de tutela y su resolución. La protección contendrá un mandato para que el emplazado actúe o se abstenga de hacerlo, según corresponda, siendo el fallo de inmediato cumplimiento, pudiendo ser impugnado. En todo caso, la sentencia judicial final de tutela se remitirá a la Corte Constitucional para su revisión, contando la Corte con una Sala de Selección de Tutelas que determinará cuáles de las acciones recibidas serán escogidas

29 La jurisprudencia de la Corte ha establecido, con acierto, que la existencia de un proceso judicial o recurso disponible para la defensa del derecho, no descarta automáticamente la aplicación de la tutela, por lo que el juez debe evaluar -en el caso concreto- la efectividad de la vía ordinaria, si resulta realmente protectiva, idónea y eficaz; en caso negativo, deberá admitirse el uso de la tutela. También la Corte, en la sentencia T-225, ha establecido los alcances del "perjuicio irremediable" que hace factible el empleo de la tutela para la protección transitoria de un derecho, requiriéndose que el peligro de daño se presente como inminente, urgente, grave e impostergable (Cf. Cifuentes Eduardo: La justicia constitucional en Colombia; op. cit, p. 81). 
para su revisión; cualquier magistrado titular de la Corte o el Defensor del Pueblo pueden insistir en que se someta a revisión una tutela no acogida por la Sala de Selección, lo que originará su reexamen y una nueva decisión de la Sala, esta vez si definitiva e irrecurrible.

El procedimiento a que se sujeta la acción de Tutela está normado en el Decreto $\mathrm{N}^{\circ} 2591$ de 1991, complementado con el Acuerdo 5 de 1992 y algunas pequeñas reformas por normas ulteriores. Conocen de las acciones de Tutela, en primera instancia, los jueces o tribunales con jurisdicción en el lugar de afectación del derecho, cuya resolución deberá expedirse dentro de los diez días de interpuesta; podrá disponerse la suspensión provisional del acto reclamado. El fallo es apelable, dentro de los tres días, ante el superior jerárquico, quien cuenta con veinte días para dictar sentencia. Posteriormente, como ya se dijo, la causa se remite en revisión ante la Corte Constitucional, quien cuenta con tres meses para resolver, teniendo su sentencia efectos sólo para el caso concreto, sin perjuicio de su incidencia en la doctrina y jurisprudencia general de este tribunal.

Cabe precisar que siendo procedente la acción de Tutela contra actos u omisiones de autoridad pública que vulneran derechos constitucionales, debemos entender como tales a los servidores públicos y a toda persona que ejerza potestades y competencias estatales; ello incluye a las decisiones del Congreso o de sus comisiones que no tengan carácter normativo. Mención especial merecen las sentencias judiciales, contra las que la ley permitía la Tutela; sin embargo, la Corte consideró inconstitucional tal disposición, por estimar que vulneraba la cosa juzgada y la autonomía funcional del órgano judicial (Sentencia C-593 de 1992). La Corte admite excepcionalmente la Tutela contra sentencias en casos donde las autoridades judiciales incurran en las llamadas "vías de hecho", es decir, una actuación o abstención clara y manifiestamente arbitraria que vulnera derechos fundamentales de las partes y configura una extralimitación judicial ${ }^{30}$.

Con respecto a los particulares contra quienes procede interponer una acción de Tutela, la ley la habilita frente a entidades prestadoras de servicios públicos, organizaciones privadas ante las que el solicitante está en situación de subordinación o indefensión, instituciones ante las que se haya ejercido infructuosamente la acción de hábeas data, medios 
de comunicación social que no atiendan la exigencia de rectificación de informaciones inexactas; contra quienes violen la prohibición de esclavitud, servidumbre o trata de seres humanos; contra particulares que afecten la vida o integridad de personas que se encuentren ante ellos en situación de subordinación o indefensión; y contra el particular que actúe en ejercicio de funciones públicas ${ }^{31}$.

El Tribunal Constitucional del Perú es competente para conocer, en última y definitiva instancia, del recurso extraordinario que se interponga en las acciones de hábeas corpus, amparo, hábeas data y de cumplimiento que hayan sido denegadas en sede judicial. Dicho recurso sólo puede ser planteado dentro de los quince días posteriores a la notificación de la resolución judicial que deniega la acción, teniendo derecho a promoverlo el demandante más no así el demandado. Las acciones de hábeas corpus, amparo y hábeas data proceden contra el hecho u omisión de autoridades, funcionarios o personas particulares que amenazan o vulneran un derecho constitucional. Su diferencia reside en los derechos específicos que cada una de ellas protegen:

- El hábeas corpus protege la libertad personal y los derechos conexos con ésta, tales como la seguridad personal, integridad, libertad de tránsito, derechos del detenido a no ser incomunicado ni maltratado, a ser asistido por un defensor, etc.).

- El hábeas data cautela el derecho a solicitar y obtener libremente la información de carácter general de que disponen las entidades públicas, con la sola obligación de pagar el costo que suponga la atención del pedido; así como del derecho a impedir que los servicios informáticos -públicos o privados- suministren informaciones que vulneren la intimidad personal o familiar.

- La acción de amparo resguarda todos los demás derechos constitucionales, no siendo procedente contra normas legales ni ante las resoluciones judiciales emanadas de un proceso regular.

En general, la acción de hábeas corpus se interpone ante cualquier juez penal, sin importar el turno; mientras que son competentes para conocer de las acciones de amparo y hábeas data son los jueces civiles, de acuerdo al turno respectivo. Sin embargo, en Lima (la capital de la 
república) se han creado juzgados y una sala superior (de segunda instancia) especializados de Derecho público, que concentran todas las acciones de garantía que allí se interpongan. Las leyes $\mathrm{N}^{\circ} 23506$ y $\mathrm{N}^{\circ}$ 25398 regulan los procesos de hábeas corpus y amparo, mientras que la Ley $\mathrm{N}^{\circ} 28301$ los procedimientos de hábeas data y de cumplimiento; la Ley $\mathrm{N}^{\circ} 26435$, norma orgánica del Tribunal Constitucional, regula la tramitación de todas estas acciones ante dicho Tribunal. El proceso ante el Poder Judicial tiene dos instancias, luego de lo cual procede el recurso extraordinario ante el TC.

$\mathrm{Al}$ conocer de las resoluciones judiciales denegatorias de las acciones de hábeas corpus, amparo, hábeas data, el Tribunal Constitucional se pronuncia sobre el fondo y la forma del asunto. Cuando estime que ha existido un vicio de forma en la resolución recurrida, declara su nulidad y manda que se reponga al estado en que se cometió el error, devolviéndola a la instancia judicial pertinente para que subsane tal deficiencia. El TC debe dictar sentencia en el término de diez días, tratándose de acciones de hábeas corpus; siendo de veinte días el término para la resolución de las acciones restantes. Ante el Tribunal no se pueden ofrecer nuevas pruebas ni alegares hechos nuevos. La sentencia del TC pone fin al proceso y agota la jurisdicción nacional interna, pudiendo recurrirse luego ante la jurisdicción internacional en materia de derechos humanos.

Es importante anotar que, de conformidad con la Cuarta de las Disposiciones Finales y Transitorias de la Constitución Peruana de 1993, "las normas relativas a los derechos y a las libertades que la Constitución reconoce se interpretan de conformidad con la Declaración Universal de los Derechos Humanos y con los tratados y acuerdos internacionales sobre las mismas materias ratificados por el Perú". Asimismo, que según la última parte del Art. $200^{\circ}$ de la referida Carta Política, incluso durante la vigencia de los regímenes de excepción (estados de emergencia o de sitio) los jueces deberán admitir las acciones de hábeas corpus y amparo que se interpongan con relación a derechos suspendidos o restringidos, efectuando el control de la causalidad, razonabilidad y proporcionalidad de la afectación ocasionada en el caso concreto.

En Bolivia, la protección de los derechos constitucionales se realiza a través de las acciones (denominadas recursos) de hábeas corpus y amparo, previstos en los artículos $18^{\circ}$ y $19^{\circ}$, respectivamente, de la Constitución. Estas acciones se tramitan ante el Poder Judicial, pero el 
fallo final será necesariamente elevado de oficio en revisión al Tribunal Constitucional.

El hábeas corpus puede interponerlo «toda persona que creyera estar indebida o ilegalmente perseguida, detenida, procesada o presa»; en tal supuesto, la persona afectada o cualquiera en su nombre, podrán demandar que se cumplan las formalidades legales acudiendo ante la Corte Superior de Distrito o un Juez de Partido a su elección (en las capitales de departamento) y en las provincias ante el Juez de Partido o (donde no lo hubiere) ante el Juez Instructor. La autoridad judicial señalará inmediatamente día y hora para la audiencia pública, que se verificará dentro de las veinticuatro horas, debiendo presentarse al accionante y concurrir la autoridad demandada, sin que ésta pueda excusarse ni desobedecer el requerimiento. Se dictará sentencia en la misma audiencia, disponiendo la libertad del demandante, su puesta a disposición de la autoridad competente o la subsanación de las irregularidades, según corresponda; la sentencia se ejecutará en el acto, sin perjuicio de su elevación en consulta ante el TC dentro de las veinticuatro horas.

Es importante precisar que las autoridades o personas particulares que se resistan a las resoluciones judiciales dictadas en los procesos de hábeas corpus, serán sometidos al juez penal para su juzgamiento por delito de atentado contra las garantías constitucionales. Cuando la sentencia declare fundada la demanda, incluso si hubieran cesado la detención o persecución ilegales o arbitrarias, el juez impondrá a la autoridad demandada el pago de daños y perjuicios, procediendo a determinar su monto; podrá disponer la retención de haberes o el embargo de bienes para asegurar el cumplimiento de la reparación. Ya en el Tribunal Constitucional, la Comisión de Admisión procederá dentro de las cuarentiocho horas al sorteo del expediente y el magistrado designado, en un término similar, formulará su pronunciamiento. El TC deberá, dentro de los cinco días posteriores al sorteo, resolver confirmando o revocando la sentencia objeto de revisión. Cuando la sentencia judicial hubiera desestimado la acción y el Tribunal la revoque, dispondrá la inmediata libertad del detenido o su sometimiento a la autoridad competente, notificando al juez para la ejecución de la orden y para que determine los daños y perjuicios.

En cuanto al amparo, se define como un proceso sumarísimo que procede «contra los actos ilegales o las omisiones indebidas de los funcionarios o particulares que restrinjan, supriman o amenacen restringir 
o suprimir los derechos y garantías de la persona reconocidas por la Constitución y las leyes». Se requiere para su procedencia que no exista otro medio o recurso legal idóneo o efectivo para la protección del derecho reclamado. Se interpone ante la Corte Superior de Distrito, en las capitales de departamento, y ante el Juez de Partido, en las provincias; sea por el afectado o su representante, pudiendo promoverlo de oficio el Ministerio Público cuando no pueda hacerlo la persona afectada. La autoridad judicial, de oficio o a pedido del actor, podrá disponer la adopción de medidas cautelares tendientes a proteger el derecho afectado o la eficacia del proceso.

Se citará a audiencia pública, donde la autoridad o persona particular emplazadas deberán presentar la información dentro de las cuarentiocho horas, procediéndose inmediatamente después a dictar sentencia. La sentencia que declara fundada la acción, de comprobarse la vulneración reclamada, se ejecutará inmediatamente, sin perjuicio de su elevación en revisión ante el TC dentro de las veinticuatro horas. El magistrado del Tribunal Constitucional que reciba el expediente por sorteo, emitirá su pronunciamiento dentro de los cinco días; el TC dictará sentencia dentro de los diez días siguientes al sorteo, confirmando o revocando la sentencia sujeta a revisión. Serán de aplicación las normas referidas a la fijación de daños y perjuicios y a la responsabilidad penal de las autoridades o particulares autores de la vulneración, así como la sanción a quienes se resistan a cumplir los mandatos judiciales dictados en el amparo.

\section{Las resoluciones de los Tribunales Constitucionales y su relación con la Corte Suprema o el Poder Judicial}

Con motivo del control de constitucionalidad de las leyes y normas realizado por los órganos judiciales ordinarios, de modo incidental o para el caso concreto (control «difuso») en cualquier tipo de procesos, se entabla una relación con los tribunales constitucionales en la medida que se dispone en determinados ordenamientos jurídicos que las resoluciones de aquéllos serán sometidos a la revisión o decisión final de éstos. Esta es la situación imperante en Ecuador y Bolivia, cuyos tribunales constitucionales asumen la voz definitiva en cuanto al eventual carácter inconstitucional de una ley o norma inaplicada por el órgano 
judicial, buscando crear una mayor certeza y estabilidad frente a los riesgos de dispersión o contradicciones susceptibles de producirse en el marco de sistemas difusos. El Tribunal Constitucional ejerce así un control que tiende a resultar más "concentrado" o "unificador", a pesar que su resolución limita sus efectos al caso concreto.

Conviene recalcar que esta revisión, de oficio o por apelación, que realiza el Tribunal o Corte Constitucional no es equiparable a la llamada "cuestión de inconstitucionalidad", aunque puede producir algunos efectos prácticos similares. $Y$ es que en el caso que comentamos, los órganos judiciales emiten una resolución sobre la constitucionalidad de la norma involucrada en la controversia concreta -que será objeto de confirmación o revocación por el TC- en vez de remitir la "cuestión» en consulta ante el Tribunal Constitucional. No queremos soslayar que resulta peculiar (y hasta contradictorio) el camino seguido en el Ecuador, puesto que la inaplicación de la norma inconstitucional en el caso concreto, dispuesta por la sala de la Corte Suprema o el tribunal de última instancia, quedará firme a pesar que se impone remitir un informe ulterior al Tribunal Constitucional, para que éste emita una decisión, de carácter general y obligatorio, al respecto. Sin embargo, la declaración del TC no afectará lo resuelto por el órgano judicial en el caso particular.

Mención especial merece también el caso peruano donde, por tratarse de un sistema "dual o paralelo», las resoluciones del Poder Judicial o la Corte Suprema (limitadas a la inaplicación de la norma inconstitucional al caso concreto) no son objeto de remisión o revisión ante el Tribunal Constitucional. Sin embargo, la Ley Orgánica del TC dispone expresamente que los jueces y tribunales ordinarios no podrán inaplicar (ejerciendo el control "difuso») las normas cuya constitucionalidad haya sido confirmada por el Tribunal Constitucional, criterio que resulta razonable para guardar la coherencia y unidad del sistema. Demás está reiterar que en los casos de Colombia y Chile tampoco existe remisión al Tribunal o Corte Constitucional de las sentencias judiciales que disponen la inaplicación de una ley o norma por considerarla inconstitucional.

Los procesos constitucionales de protección de los derechos fundamentales son un campo donde, con la única excepción del caso de Chile, se relacionan y participan conjuntamente los órganos judiciales ordinarios y los tribunales constitucionales. Esto sucede con las accio- 
nes de tutela en Colombia; de hábeas corpus, amparo y hábeas data, en Perú y Ecuador; y de hábeas corpus y amparo en Bolivia. Aquí los jueces o tribunales actúan como instancia inicial (en una o dos instancias) correspondiendo al TC la decisión definitiva, lo cual parece razonable por ser este órgano a quien corresponde el desarrollo de una doctrina y jurisprudencia que tiendan a la mejor protección de los derechos y a la interpretación de sus alcances.

Actualmente lo más corriente es excluir a la Corte Suprema de participación en esta materia, para evitar eventuales roces o discrepancia de criterios entre ésta y el Tribunal Constitucional. Es por ello que en el caso peruano, la Corte Suprema sólo interviene como segunda instancia cuando las acciones de hábeas corpus o de amparo han sido interpuestas contra una resolución judicial. Por último, coincidimos con el profesor Humberto Nogueira cuando sostiene la conveniencia de que, a través de una futura reforma, el Tribunal Constitucional de Chile asuma también competencia para conocer -en última instanciade los procesos destinados a la protección de los derechos fundamentales, tal como sucede con el conjunto de tribunales constitucionales ${ }^{32}$.

\section{Apreciación de conjunto y reflexiones finales}

Diversos países latinoamericanos, bajo la influencia de la experiencia de los Estados Unidos de América del Norte, fueron acogiendo tempranamente - desde mediados del siglo XIX- el control jurisdiccional de la constitucionalidad de las leyes mediante el denominado "sistema difuso" o «americano». En Europa, en cambio, este proceso resulta bastante posterior, pues los tribunales constitucionales -a través de los cuales este control se hace efectivo-surgieron recién durante el período de entreguerras y luego de la culminación de la Segunda Guerra Mundial.

No obstante, en épocas más recientes, países latinoamericanos como Guatemala, Chile, Ecuador, Perú, Colombia y Bolivia han incorporado a sus regímenes políticos y jurídicos tribunales constitucionales, dando

32 Cf. Humberto Nogueira Alcalá: «Reflexiones sobre las competencias de la Corte Suprema y el Tribunal Constitucional en materia de control de constitucionalidad»; en, Corte Suprema y Tribunal Constitucional: competencias y relaciones; Revista Ius et Praxis; año IV, $\mathrm{N}^{\circ} 1$ (1998); Facultad de Ciencias Jurídicas y Sociales de la Universidad de Talca (Chile); pp. 307-308. 
lugar a sistemas de jurisdicción constitucional de carácter «mixto» o de tipo «dual o paralelo», dado que coexisten en un mismo ordenamiento jurídico el control "difuso" a cargo del Poder Judicial y el "concentrado" en el Tribunal o Corte Constitucional, en unos casos mezclándose y en otros simplemente como sistemas yuxtapuestos. Sin duda que estos sistemas "mixtos" o "duales" expresan una "creatividad" que trasciende la mera incorporación mecánica de los modelos "clásicos» de control «difuso" o "concentrado"; revisten, además, especial interés de estudio por las peculiaridades que le son propias en cada caso nacional.

Como señaláramos al empezar este trabajo, consideramos que esta instauración de sistemas "mixtos" o "duales" de jurisdicción constitucional, antes que producto de creaciones teóricas o de modelos preconcebidos, ha estado fuertemente condicionada por la vigencia previa del sistema de control difuso a cargo de jueces y tribunales ordinarios, en países latinoamericanos donde se decidió posteriormente incorporar un Tribunal Constitucional. Pero también, en mucho, parece ocasionada por la resistencia de las Cortes Supremas nacionales a perder o ceder todas o algunas de sus atribuciones en este campo a manos de los nuevos tribunales constitucionales. A su vez, respondería al propio recelo de los órganos políticos de otorgar a estos tribunales constitucionales amplias competencias exclusivas y excluyentes, no sólo porque irían en "desmedro» del Poder Judicial sino también, por el temor de que lleguen a ostentar un poder demasiado importante o independiente frente al parlamento y el gobierno.

Para hacer aún más complejo el cuadro que recoge el conjunto de modalidades adoptadas por los sistemas de jurisdicción constitucional en los países latinoamericanos, en algunos casos se ha optado por combinar ciertos elementos de los sistemas "difuso" y "concentrado", no sólo sin adoptar de manera integral o "pura" ninguno de ambos sino -incluso- a veces sin establecer un Tribunal Constitucional. Se trata de aquellos países que cuentan con un sistema "difuso", a cargo de todos los tribunales judiciales ordinarios y con decisión limitada al caso concreto, que además acogen el principio del stare decisis y confieren a la Corte Suprema (en forma "concentrada") el monopolio de la potestad de declarar con efectos generales la inconstitucionalidad de las leyes, siendo su decisión obligatoria para todos los tribunales y jueces ordinarios ${ }^{33}$.

33 Cf. Francisco Fernández Segado: «El control de la constitucionalidad en 
Pero si algo debe recalcarse, es que esta adopción de sistemas jurisdiccionales de control y defensa de la Constitución estuvo marcada en la experiencia de muchos países latinoamericanos - más como un fenómeno de tipo formal que real, es decir, sin que alcanzara efectiva vigencia en la realidad por la debilidad o sumisión de los órganos judiciales a los poderes políticos de turno. La ulterior incorporación de los Tribunales Constitucionales en ciertos países, expresa tanto este descontento y decepción frente al discreto o nulo papel cumplido por los órganos judiciales ordinarios en este campo, como la expectativa de que por esta vía pueda avanzarse en la afirmación del Estado de Derecho, la supremacía constitucional y los derechos fundamentales.

Las características y competencias de estos Tribunales Constitucionales latinoamericanos presentan pues, en cada país, muchos elementos comunes pero también diversos rasgos particulares, sin duda resultado de sus experiencias históricas y políticas específicas. Puede afirmarse que los Tribunales y Cortes Constitucionales de Colombia, Ecuador, Perú y Bolivia gozan de significativa autonomía orgánica, funcional y jurisdiccional frente al Poder Judicial y la Corte Suprema, a pesar que los tribunales boliviano y colombiano integren formalmente también el poder o rama judicial, respectivamente. La dependencia relativa del Tribunal Constitucional de Chile con respecto a la Corte Suprema -a pesar de lo separado de sus competencias y atribuciones- resulta, más bien, bastante señalada.

En cuanto a la composición de los tribunales constitucionales, una de las más serias recomendaciones formuladas por los estudiosos de la jurisdicción constitucional, tanto desde el punto de vista teórico como de la experiencia concreta, es que estos órganos no deben estar (preferentemente) conformados por magistrados llegados desde la carrera judicial. Se estima, creemos que con fundamento, que la naturaleza de las funciones que ejercen dichos tribunales requiere de sus magistrados criterios especiales de interpretación constitucional y de comprensión del fenómeno político, cualidades que no suelen ser muy comunes ni difundidas entre quienes provienen de la judicatura ordinaria, sobre

Iberoamérica: sus rasgos generales y su génesis en el pasado siglo»; en, Pensamiento Constitucional $N^{\circ} 3$; revista de la Maestría en Derecho Constitucional de la Pontificia Universidad Católica del Perú; (1996); pp. 231-264. Véase también el trabajo de Allan Brewer Carías ya citado anteriormente. 
todo por el predominio de un apego al positivismo formalista y a la subordinación reverencial hacia la ley y al poder político imperante.

Partiendo de este criterio, ciertamente el caso más delicado sería el de la composición del Tribunal Constitucional chileno, pues tres de sus siete miembros provienen de la designación de la Corte Suprema y otros dos más deben haberse desempeñado (por varios años) como abogados integrantes de dicha corte; lo cual suele incidir en el razonamiento del tribunal $y$, sobre todo, conspira contra su autonomía real con respecto a la Corte Suprema. El caso ecuatoriano está en una situación intermedia, pues aunque sus nueve miembros son elegidos por el Congreso, provienen de ternas propuestas por los distintos Poderes Públicos y por organizaciones sociales, siendo muy peculiar el incluir miembros designados por entes gremiales de los ámbitos laboral, social y productivo. Los miembros de los tribunales constitucionales de Perú y Bolivia son íntegra y exclusivamente elegidos por el Congreso, lo que torna al criterio para la selección de los magistrados mucho más dependiente de la correlación de fuerzas políticas y los acuerdos parlamentarios. En cambio, aunque todos los magistrados de la Corte Constitucional Colombiana son elegidos por el Senado, el hecho que los candidatos provengan de ternas propuestas por el Gobierno, la Corte Suprema y el Consejo de Estado, reduce el margen de discrecionalidad de la decisión parlamentaria y puede asegurar mayor pluralismo político en los nombramientos.

Una característica de la mayoría de los tribunales constitucionales andinos, es el reducido número de sus magistrados en especial si lo comparamos con los tribunales europeos. Así, el tribunal de Bolivia tiene sólo cinco miembros, el peruano y el chileno siete, mientras que el ecuatoriano y el colombiano cuentan con nueve magistrados. El tema es apremiante en Bolivia, dado su amplia gama de competencias; siendo cuestionable que en el caso del tribunal peruano (a pesar de su experiencia y de las altas mayorías exigidas para ciertas decisiones) no se contemple la existencia de magistrados suplentes. También luce reducida la duración del mandato personal de los magistrados en Ecuador, lo que puede afectar el desarrollo institucional del tribunal y su estabilidad, exponiéndolo más a la injerencia política en los nombramientos. Ello contrasta con el período mucho más extenso previsto en los tribunales de Bolivia y Colombia, de diez y ocho años, respectivamente, sin posibilidad de reelección inmediata. 
En cuanto a su organización, los cinco tribunales constitucionales andinos tienen como regla el actuar en una única Sala (o en Plenaria) lo cual en algunos casos -como el de Bolivia- parece estar determinado por el reducido número de sus miembros. Una excepción importante, digna de ser tomada como ejemplo, es el de la Corte Constitucional de Colombia, donde para la revisión de los casos de acción de Tutela se han establecido nueve salas, cada una presidida por uno de los magistrados e integradas por otros dos, de modo que cada magistrado forma parte de tres Salas de Tutela. Este criterio de organización pensamos que podría acogerse, sin mayores dificultades prácticas, en los tribunales constitucionales del Perú y Ecuador (que cuentan con siete y nueve miembros, respectivamente) para efectos de la revisión de los procesos constitucionales destinados a la protección de los derechos fundamentales.

Las resoluciones en estos tribunales constitucionales se adoptan por la mayoría de votos de sus miembros, en algunos casos por mayoría simple y en otros ésta debe ser absoluta (más de la mitad de votos favorables). Un caso particularmente cuestionable es el del Tribunal Constitucional del Perú, que para declarar la inconstitucionalidad de una ley o norma de rango legal requiere del voto favorable de seis de sus siete miembros; en caso de no alcanzarlos, y a pesar que una mayoría absoluta haya determinado la inconstitucionalidad del precepto objetado, la ley orgánica del tribunal manda desestimar la acción y confirmar la constitucionalidad de la norma, no pudiendo ésta ser nuevamente recurrida ante el TC ni inaplicada en sede judicial. Estamos ante un claro caso donde el Congreso Peruano, al normar el ejercicio de las atribuciones del Tribunal, optó deliberadamente -a pesar de las múltiples críticas que recibió acerca de lo pernicioso de dicha decisión- por un sistema destinado a dificultar la posibilidad de declaración de inconstitucionalidad de leyes o normas dictadas por el propio Congreso o el Gobierno.

Las competencias y atribuciones de estos tribunales constitucionales resultan, en general, bastante amplias, excediendo las que en los modelos clásicos suelen corresponder a estos órganos. Comprenden -en la mayoría de casos- el control de constitucionalidad de leyes y normas, abarcando muchas veces tanto el control preventivo como el a posteriori y el consultivo; la revisión de resoluciones judiciales recaídas en procesos de protección de los derechos constitucionales; y la resolución de 
conflictos de competencias entre los órganos estatales. En el lugar más disminuido se encontraría nuevamente el Tribunal Constitucional chileno, pues aunque el número de sus competencias puede considerarse amplio, el control de constitucionalidad de las leyes que ejerce es esencialmente preventivo, careciendo además de toda intervención en cuanto a la protección de los derechos fundamentales.

Mención especial merecen las atribuciones de tribunales constitucionales como los de Bolivia y Ecuador referidas al control de los actos normativos y administrativos dictados por un amplio número de órganos y autoridades gubernamentales. También las competencias de los tribunales de Colombia y Chile respecto al control de convocatorias a referéndum y consultas populares o procesos de reforma constitucional; debiendo agregarse en el caso chileno el control de la adecuación constitucional de partidos y movimientos políticos, así como la dilucidación de impedimentos o inhabilidades aplicables al Presidente de la República, los congresistas o quienes deben ser nombrados como ministros. Sería pertinente determinar lo positivo o contraproducente que pueden resultar muchas de estas amplias y variadas competencias atribuidas a ciertos tribunales constitucionales, sobre todo en cuanto a la incidencia que puedan tener en el cumplimiento de las funciones que les son inherentes y más relevantes.

El control de la constitucionalidad de las leyes y normas generales presenta un carácter bastante completo e integral en la Corte de Colombia, así como en los tribunales de Bolivia y Ecuador, que ejercen simultáneamente (con diversos matices y alcances particulares) control preventivo, a posteriori y consultivo de las normas de rango legal. Cabe destacar, como un caso singular en la región, la potestad de la Corte de Constitucionalidad de Guatemala de disponer la suspensión provisional (con carácter general) de la vigencia de la norma acusada de inconstitucional sometida a su conocimiento.

En materia del control preventivo de la constitucionalidad de los proyectos de ley, todos estos tribunales constitucionales, a excepción del peruano, poseen diversas atribuciones en este campo, rasgo que es preponderante en la función del TC de Chile. Nuevamente los cuatro tribunales, a excepción del peruano, realizan también el control preventivo de la constitucionalidad de los tratados y convenios internacionales, antes de su aprobación por el Congreso o de su ratificación por el Presidente (esto último en el caso de Colombia). Si bien el TC del 
Perú puede ejercer el control de los tratados (a través de la acción de inconstitucionalidad) sólo cabe realizarlo a posteriori, es decir, luego de que hayan sido aprobados y ratificados. Ello resulta paradójico y contraproducente, por los efectos para las relaciones internacionales que acarrearía una eventual declaratoria de inconstitucionalidad de un tratado ya aprobado y ratificado por el Estado.

Los casos de los tribunales constitucionales de Perú y Chile se presentan como los más limitados, en comparación con los restantes tribunales de la región, en cuanto a su potestad de ejercer el control de la constitucionalidad de las normas legales. El TC peruano sólo realiza un control a posteriori de las normas con rango legal vigentes en un proceso que, como ya hemos anotado, muestra en su regulación actual demasiadas restricciones para un efectivo y eficaz control y declaración de inconstitucionalidad. El TC chileno, por su parte, está casi limitado al control preventivo obligatorio de la constitucionalidad de los proyectos de leyes orgánicas y leyes interpretativas de la Constitución, así como al control preventivo facultativo de los proyectos de ley durante su tramitación parlamentaria, cuando su eventual inconstitucionalidad sea objeto de consulta u objeción. Obviamente se impone una revisión y ampliación de las competencias de ambos Tribunales en este campo, con mayor razón en el caso del TC chileno.

En cuanto a la legitimación para interponer la acción directa de inconstitucionalidad, dirigida al control abstracto de las leyes y normas de carácter general, destaca nítidamente el caso colombiano donde existe una antigua tradición de reconocer una acción popular -de carácter público- que habilita a cualquier persona a recurrir ante la Corte Constitucional con este propósito. Contrariamente, el tribunal constitucional chileno no puede ser objeto de ninguna acción por parte de los ciudadanos, sea individualmente o en forma grupal, ni de organizaciones sociales. También en Ecuador se contempla la posibilidad de que una sola persona promueva esta acción, siempre que su pedido sea respaldado por tres abogados o por el Defensor del Pueblo, respectivamente. En el Ecuador pueden interponer esta acción mil ciudadanos, mientras que en el Perú se requieren cinco mil, siendo factible que en el caso peruano lo hagan también los Colegios Profesionales, en asuntos de su competencia.

Digamos que lo tradicional en la legitimación reconocida para interponer la acción de inconstitucionalidad, es concederla al Presidente 
de la República, y a un número determinado de congresistas, salvo en el caso de Guatemala donde ambos están excluidos de esta potestad; siendo peculiar el caso de Bolivia donde basta que la acción sea promovida por un senador o diputado, lo que crea el riesgo de un exceso de politización en el uso de este recurso. El Defensor del Pueblo cuenta con legitimación ante todos los Tribunales Constitucionales, salvo en el caso de Chile.

Los Tribunales de Bolivia y Ecuador conocen, en apelación o revisión, de las sentencias judiciales de inaplicación dictadas en procesos donde se realiza un control concreto o incidental de la constitucionalidad de ciertas normas. Esta remisión para la decisión final del Tribunal Constitucional, resulta muy positiva pues tiende a generar una suerte de control más unificado y "concentrado", que reduzca los riesgos de dispersión o sentencias judiciales contradictorias susceptible de generarse en el marco del control difuso. No obstante, resulta insuficiente la solución prevista en el sistema del Ecuador, pues aunque las sentencias de inaplicación dictadas por salas de la Corte Suprema o tribunales de última instancia judicial se remitan en informe al TC, para que éste confirme la inconstitucionalidad e inaplicación general y obligatoria de la norma, su decisión no tiene efecto alguno para el caso concreto ya resuelto por el órgano judicial.

En todo caso, consideramos preferible y recomendable que se adopte la institución de la "cuestión de inconstitucionalidad», a ser planteada ante los tribunales constitucionales (allí donde éstos existen) cuando se presente la necesidad de dilucidar la constitucionalidad de una norma en cualquier tipo de proceso judicial. Con ello no sólo se gana en certeza y estabilidad de las decisiones jurisdiccionales, sino que se evitan eventuales conflictos de interpretación o enfrentamientos entre el Tribunal Constitucional y la Corte Suprema o los restantes jueces y tribunales judiciales ordinarios.

La competencia para ejercer la protección de los derechos fundamentales, a través de procesos o garantías constitucionales especiales, es otra característica de la mayoría de tribunales constitucionales de América Latina, excepto el de Chile, función que comparten con el Poder Judicial aunque asumiendo el TC la última instancia de decisión. Mientras que los Tribunales del Perú y Ecuador conocen de las acciones de hábeas corpus, amparo y hábeas data (debiendo agregar en el caso peruano también la acción de cumplimiento, que no es propia- 
mente una vía de protección de derechos), en Bolivia el TC revisa las resoluciones judiciales de hábeas corpus y amparo, y en Colombia esta competencia sólo se refiere al amparo, denominado Tutela en el ordenamiento colombiano.

A diferencia del caso peruano, donde el Tribunal Constitucional sólo conoce (mediante el recurso extraordinario) de las acciones de hábeas corpus, amparo y hábeas data que hayan sido denegadas o desestimadas en sede judicial, los tribunales y cortes constitucionales de Ecuador, Colombia y Bolivia reciben necesariamente, en apelación o revisión, todas las decisiones judiciales recaídas en los procesos de garantías para la protección de derechos que les han sido encomendados. Cabe puntualizar, como rasgos particulares, que en el Ecuador el hábeas corpus no se presenta ante los tribunales judiciales, sino ante el alcalde municipal. Y que en Colombia, la Corte Constitucional cuenta con una Sala de Selección de Tutelas, que determina cuáles del conjunto de acciones recibidas serán sujetas a revisión y decisión de la Corte.

En definitiva, más allá de sus semejanzas y particularidades, la vida de cada uno de estos Tribunales Constitucionales y el impacto de su labor vienen siendo bastante distintos. Sin duda que ello suele estar influenciado por la solidez o inestabilidad institucional de los sistemas jurídicos y políticos nacionales donde ejercen sus funciones; pero también habría que agregar, como un factor muy importante y -a vecesdecisivo, la composición de este órgano y la actuación asumida por sus miembros. Es grande la responsabilidad de las instituciones que designan a los magistrados de los tribunales o cortes constitucionales: de ellas depende escoger a personas con solvencia jurídica y moral, con independencia política y entereza, que seguramente estarán mejor preparadas para ejercer esta función con acierto y eficacia; $u$ optar por colocar a personas sin demasiados merecimientos propios, en base a consideraciones de funcionalidad política o de conveniencia a sus intereses particulares.

La labor que vienen cumpliendo los Tribunales Constitucionales del área andina, depende -en muy alta medida- de la actuación de sus magistrados. Los aportes de la jurisprudencia y doctrina emanadas de la Corte Constitucional de Colombia, tanto en la resolución de las acciones de inconstitucionalidad como de tutela, sin duda que ofrecen una positiva contribución no sólo para su país sino para los otros Tribunales Constitucionales. El joven Tribunal Constitucional de Bolivia 
viene dando pasos importantes de consolidación y legitimación en el difícil sistema político de su país.

En cambio, la experiencia del Tribunal Constitucional del Perú parece estar signada por el infortunio pues, a las propias limitaciones de su actuación, se ha sumado la ación del régimen autoritario del Presidente Fujimori que en dos ocasiones ha destruido dicha institución. En el primer caso, clausurándolo luego del autogolpe de estado de abril de 1992; y luego -por segunda vez- cuando tras su reinstauración con la Carta de 1993, la mayoría parlamentaria oficialista decidió arbitrariamente la destitución de tres de los magistrados del TC, en clara represalia política por su pronunciamiento jurisdiccional en contra de una nueva e inconstitucional postulación para la reelección presidencial inmediata. Ello ha determinado que este diezmado Tribunal Constitucional peruano, carezca en la actualidad de solvencia, significación y legitimidad.

Creemos por ello que la experiencia de los Tribunales Constitucionales en la región andina resulta, en general, positiva y abierta a nuevas y mayores posibilidades de desarrollo y consolidación. La necesidad de redefinir el Tribunal Constitucional de Chile y de «refundar» el TC del Perú, son pasos que se imponen perentoriamente. Es evidente que el fortalecimiento y eficacia de estos tribunales está ligado, y depende mucho, del grado de consolidación institucional del régimen democrático en sus respectivos países.

Pero también resulta claro -estamos convencidos de ello- que muchas veces lo determinante para avanzar será el efectivo y firme compromiso concreto con la institucionalidad democrática y la vigencia de los derechos humanos, como rasgos que definan la actuación de dichos tribunales constitucionales y sus magistrados. De ello seguramente dependerá grandemente el futuro de los aún incipientes Tribunales Constitucionales latinoamericanos. $Y$ es por eso que en dicha convicción, y en ese compromiso, depositamos toda nuestra expectativa y fe democrática.

Lima, julio del 2000. 